\title{
Impact of in-field soil heterogeneity on biomass and yield of winter triticale in an intensively cropped hummocky landscape under temperate climate conditions
}

\author{
Muhammad Habib-ur-Rahman ${ }^{1,2}$ (D) Ahsan Raza ${ }^{1}$ - Hella Ellen Ahrends ${ }^{1,3}$. \\ Hubert Hüging ${ }^{1} \cdot$ Thomas Gaiser $^{1}$
}

Accepted: 2 November 2021 / Published online: 11 December 2021

(C) The Author(s) 2021

\begin{abstract}
Crop cultivation provides ecosystem services on increasingly large fields. However, the effects of in-field spatial heterogeneity on crop yields, in particular triticale, have rarely been considered. The study assess the effects of in-field soil heterogeneity and elevation on triticale grown in an intensively cropped hummocky landscape. The field was classified into three soil classes: $\mathrm{C} 1, \mathrm{C} 2$, and $\mathrm{C} 3$, based on soil texture and available water capacity (AWC), which had high, moderate, and low yield potential, respectively. Three elevations (downslope (DS), midslope (MS), and upslope (US)) were considered as the second study factor. An unbalanced experimental design was adopted with a factorial analysis of variance for data analysis. Temporal growth analysis showed that soil classes and elevation had significant effects. Generally, better growth was observed in C1 compared to that of C3. DS had a lower yield potential than that of MS and US. In addition, the interactive effect was confirmed, as triticale had poor growth and yield in C3 on the DS, but not on US. Crop physiological parameters also confirmed the differences between soil classes and elevation. Similarly, soil moisture (SM) content in the plow layer measured at different points in time and AWC over the soil profile had a positive association with growth and yield. The results confirmed that spatial differences in AWC and SM can explain spatial variability in growth and yield. The mapping approach combining soil auguring techniques with a digital elevation model could be used to subdivide fields in hummocky landscapes for determining subfield input intensities to guide precision farming.
\end{abstract}

Keywords Precision resource management $\cdot$ Soil texture $\cdot \mathrm{SOM} \cdot$ Available water capacity $\cdot \mathrm{DEM} \cdot$ Stomatal conductance and transpiration rate

Muhammad Habib-ur-Rahman

mhabibur@uni-bonn.de; habibagri@hotmail.com

1 Crop Science, Institute of Crop Science and Resource Conservation, University of Bonn, Katzenburgweg 5, 53115 Bonn, Germany

2 Department of Agronomy, MNS-University of Agriculture, Multan, Pakistan

3 Department of Agricultural Sciences, University of Helsinki, 00014 Helsinki, Finland 


\section{Introduction}

Feeding the ever-increasing global population with quality food requires the efficient use of limited resources for agricultural production. Resource use efficiency can be enhanced through precision farming, where agricultural management practices are adapted to the small-scale heterogeneity or "in-field variability" of plant growth conditions. Among other site-specific factors, soil is the basic unit for plant life and biodiversity and provides nutrients to plants (Cardoso et al., 2013; Powlson et al., 2011). Thus, understanding the basic processes and interactions between soil, crops, and the environment is crucial for defining the functions occurring in any agricultural system (Hatfield \& Prueger, 2015; Panagos et al., 2018). Variations in soil physical properties and resources (e.g. water) lead to soil heterogeneity at both the spatial and temporal scales (Beuschel et al., 2019; Xue et al., 2016). Spatial variability in physical and chemical soil properties leads to spatial heterogeneity in crop productivity (Wallor et al., 2018; Yao et al., 2014). Together with soil biological factors, physical properties strongly affect soil productivity and fertility and, ultimately, the amount and quality of agricultural production (Dercon et al., 2006; Techen et al., 2020; Yao et al., 2014). Therefore, knowledge regarding spatial heterogeneity is crucial for agricultural decision making and the efficient use of resources for food production. Soil being heterogeneous in structure affects the different processes of an ecosystem as well as nutrient balance. Sustainable soil management approaches are required to understand the effect of soil properties and manage them accordingly to improve soil health and reduce soil degradation and nutrient depletion under intensified continuous cropping (Chen et al., 2020; Xue et al, 2019).

Differences in soil texture lead to variation in water holding capacity, while differences in elevation within-field also affect the nutrient and water supply, especially under rain-fed conditions, and ultimately the biomass and yield production. The effect of infield soil heterogeneity and nutrient spatial variations on crop growth and production occurs at different elevations across a gradient (Dercon et al., 2006; Yang et al., 2020). Previous studies related to the effect of topography and elevation on corn, soybean, and wheat crop yield and biomass have revealed the yield variations according to different locations at specific elevation points under a temperate humid climate (Huang et al., 2008; Kravchenko et al., 2003). Corn and soybean growth and biomass of an undulating field (temperate humid climate) at topographical depressions are boosted due to favorable hydrological and edaphic factor combination compared to other crops within the same field (Beehler et al., 2017; Kravchenko \& Bullock, 2000). Higher spatial soil variability and soil carbon content occur across diverse topographical fields compared to those in uniformly higher terrain. Other sources of variation, including soil moisture (SM), water holding capacity, and temperature, occur due to topographical differences and influence many soil properties (Hao et al., 2010; Huang et al., 2008; Kravchenko et al., 2003). Topography and elevation significantly contribute to spatial variability related to soil physical properties that are relatively strongly associated with soil organic carbon (SOC) and SOM contents. SOC and SOM are highly correlated with soil water retention capacity, which ultimately affects crop growth, biomass, and yield (Kumhálová et al., 2011; Ladoni et al., 2016; Poffenbarger et al., 2020). SOM content affects soil aggregation, which leads to variation in the water retention capacity and soil structure and generally affects the overall soil properties (Tariq et al., 2018). Soils at convex slopes at lower elevations are usually characterized by accumulated sediments from eroded soil material from higher elevations, leading to a convergence of soil quality, 
hence, crop growth. Therefore, it is important to assess the effect of topography on soil variability and soil properties and their interactions and further impacts on crop growth, biomass, and yield. However, to date, relatively few studies under temperate climate conditions have been conducted, that considers all of these interactive factors and their effects on triticale.

Assessing and identifying the spatial soil variability and its effects on crop production is a useful method for decision-making and the improvement of ecosystem services (Basso et al., 2016; Chen et al., 2021; Marchant et al., 2019; Song et al., 2020; Vieira $\&$ Gonzalez, 2003). Crop growth attributes, such as leaf area index (LAI) and biomass, are directly affected by soil water and nutrient dynamics, which are dominantly controlled by soil type and topography. The spatial heterogeneity in soil characteristics and the corresponding effects on water and nutrient availability can lead to differences in the crop LAI and biomass (Erekul \& Köhn, 2006; Guedes Filho et al., 2010; Ladoni et al., 2016; Sida et al., 2018). However, these techniques require a thorough understanding of optimal quantities and information relating to how and when to implement these techniques to enhance resource use efficiency. Recently, spatial variation as a new management method has emerged, which takes into account soil potential (Chen et al., 2021; Metwally et al., 2019). To assess and quantify spatial variation in-field soil heterogeneity, different approaches are used, with the most promising being the division of a field into subfields according to soil classes/zones related to different soil physical and chemical properties, assuming contrasting yield potential (Chen et al., 2020; Metwally et al., 2019; Yao et al., 2014). Soil mapping and zoning is a precision resource management approach for understanding the in-field soil heterogeneity and variation in crop yields, and is the most effective method of decision-making regarding crop rotation and planning for effective resource utilization (Beuschel et al., 2020; Cardinael et al., 2018). This method allows the quantitative characterization of soil heterogeneity to promote profitability and sustainable production of the agricultural system (Chen et al., 2020; Patzold et al., 2008). Precision agriculture techniques can be used to assess and evaluate in-field variation for soil properties and heterogeneity by the delineation of soil zones to understand yield variability (Castrignanò et al., 2018; Nawar et al., 2017). Mapping and assessment of soil heterogeneity and spatial variation can be conducted using different geostatistical techniques (Buttafuoco et al., 2017; Castrignanò et al., 2018). Spatial correlation and estimation techniques can be used for the prediction of soil properties at un-sampled points/locations with reasonably good accuracy, and these are helpful for soil and crop management to reduce the environmental impacts (Nawar et al., 2017; Saito et al., 2005). Understanding the spatial distribution of soil properties within a field is crucially important for site-specific/sub-field soil and crop management for sustainable production. Furthermore, it is important for soil health and improved resource use efficiency of the cropping system.

In this study, the spatial soil heterogeneity in an intensively cropped hummocky landscape was assessed in relation to the spatial variability of triticale growth and yield parameters. The study hypothesizes that in-field soil heterogeneity and elevation (topography) can affect the growth and yield of winter triticale under an intensively cropped hummocky landscape in temperate climatic conditions. Spatial data obtained from various sensors during the growing season 2019/2020 was used to understand the effect of the in-field variability of soil properties on triticale growth and yield components. More specifically, the main objectives of this study were as follows: (1) to quantify the effects of soil heterogeneity and elevation (topography) on triticale growth parameters and (2) to relate growth parameters and soil properties to triticale yield and yield components at harvest. 


\section{Material and methods}

\section{Environmental conditions of the study area}

The experimental area is located in the Löwenberger Land, Brandenburg, East Germany $\left(135^{\circ} \mathrm{W}, 105^{\circ} \mathrm{E}\right.$ and $51.3-57.7 \mathrm{~m}$ a.s.1.) which is characterized by a temperate humid climate (Fig. 1). The experimental field $(\sim 6.3 \mathrm{ha})$ is characterized by heterogonous soil conditions, with the soils having developed from glaciofluvial and glacial deposits. The landscape was formed during the last Pleistocene glaciation and is, therefore, moderately undulated. Soil texture ranges from loamy sand and silt to medium sand. The soil has low SOC content and has continuously been used for rain-fed cereal crop production over the past few decades. Soil physiochemical properties vary across the slope, depending on elevation. The field is undulating and there is a topographical depression at the foot slopes but also within the convex slope, which has led to differences in edaphic and hydrological features as well as to heterogeneity (Fig. 1, Digital Ground Model). The climate of the region is temperate and humid and shows features of a transition towards continental climates, such as long cold winters, while summers are warm, and dry spells of up to several weeks have been reported. The average rainfall in the region is $554 \mathrm{~mm} \mathrm{year}^{-1}$, which is lower than the average of the country (Gutzler et al., 2015). The average day temperature ranges from $-0.8{ }^{\circ} \mathrm{C}$ to $22.7{ }^{\circ} \mathrm{C}$ while the daily minimum and maximum temperature range from $-6.4{ }^{\circ} \mathrm{C}$ to $17.9{ }^{\circ} \mathrm{C}$ and $1.1{ }^{\circ} \mathrm{C}$ to $30{ }^{\circ} \mathrm{C}$, respectively during the wheat growing season (Fig. 2). Relative humidity remains high, normally above $65 \%$ and total rainfall during crop growing season is $503 \mathrm{~mm}$. Weather data are continuously recorded in the experimental field via sensors installed for temperature, rainfall, relative humidity, and dew point. The daily weather data during the growing seasons of the triticale crop (September 2019-July 2020) are presented in Fig. 2.

\section{Establishment of tree rows and crop management practices}

The field covers an area of $\sim 6.3$ ha with variation in elevation and undulating patterns as well as topographical depression (Fig. 1). Different tree species were planted group-wise
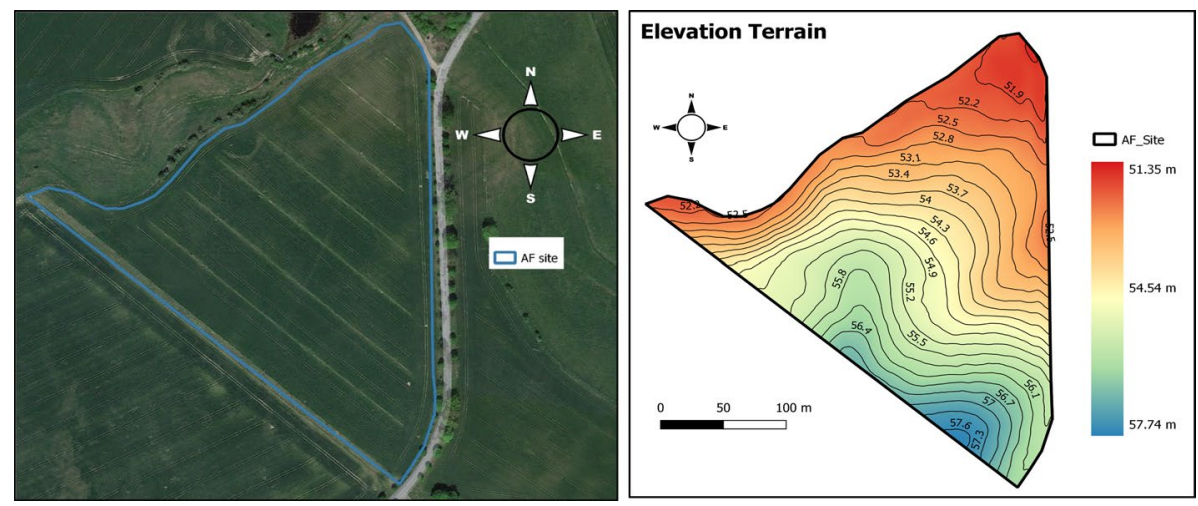

Fig. 1 Experimental site in Löwenberger Land, Brandenburg, Germany. Variation in elevation with in-field represented by elevation terrain. (Source of the image -credits to Google Earth, and DGM from https:// geobroker.geobasis-bb.de/) 


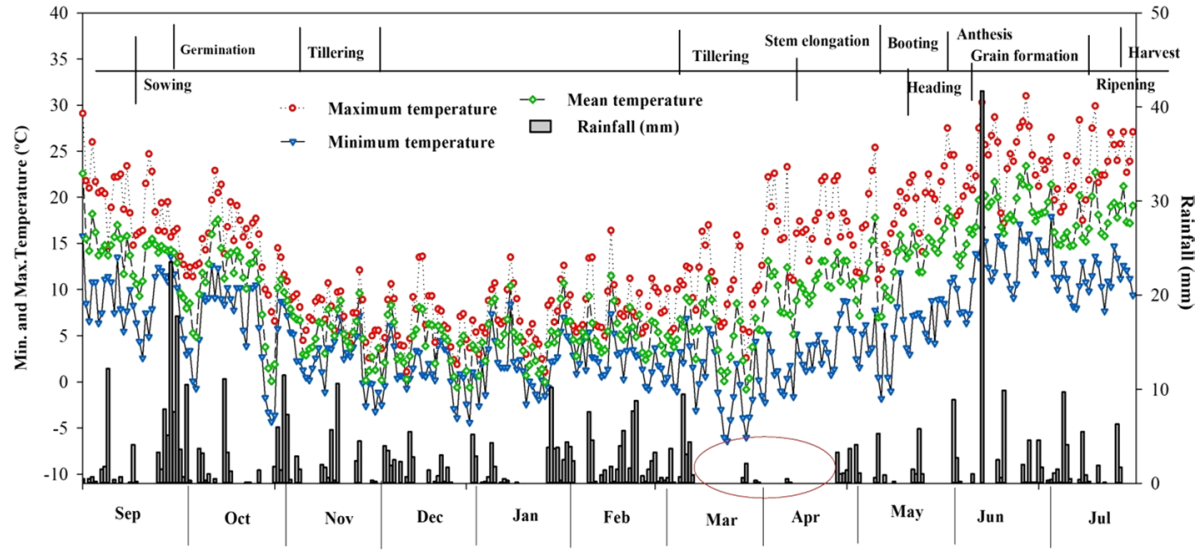

Daily weather data (September 2019 to July 2020)

Fig. 2 Daily weather data of maximum, minimum, mean temperature, and rainfall during winter triticale crop growing season related to phenological development stages from sowing to harvest using $\mathrm{BBCH}$-scale (Biologische Bundesanstalt, Bundessortenamt und Chemische Industrie). Data for LAI, biomass, plant height, physiology, soil moisture, and final harvest data was collected on mentioned dates in graphs, May 7 th $(\mathrm{BBCH}=39$, end of stem elongation), June 10th $(\mathrm{BBCH}=69$, end of anthesis and start of grain formation), and July 14th, $2020(\mathrm{BBCH}=89$, fully ripened stage)

(three trees per group) perpendicular to the slope in eight rows with variable lengths (15-363 m; Fig. 3) in summer 2017. The width of the tree strips is $2 \mathrm{~m}$, while space for crop cultivation (crop strips) between tree rows is $36 \mathrm{~m}$. There is a $10 \mathrm{~m}$ distance between the tree groups (Fig. 3). In 2019, when the growth and yield of triticale were observed,

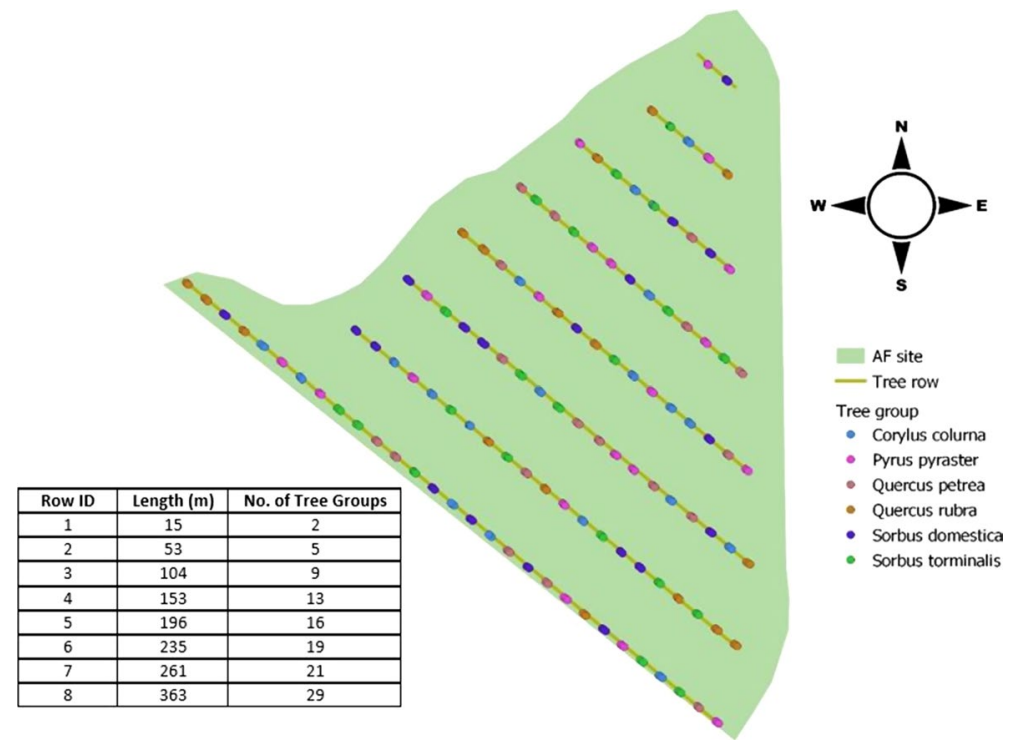

Fig. 3 Planting geometry of tree groups within the field to develop the alley cropping system presented with respect to tree species arrangement within rows and intra rows 
the trees were small and poorly developed due to extreme dry summers with heat waves in both 2018 and 2019. Due to the grouped planting of the trees, their low heights, and as the observations in the triticale crop were taken between 4 and $6 \mathrm{~m}$ from the tree groups, the influence of the trees on the measurements taken was considered to be negligible. For the management of triticale, good agronomic and best cultural practices were adopted to determine the potential of the crop under rain-fed conditions. The cultivar "Lombardo" was sown, which is widely cultivated in the region due to its unique features, such as good stability, excellent winter hardiness, highly stable yield potential, and suitability in frost and drought conditions. Details regarding field operation, fertilizer and herbicide application, and other cultural operations are provided in Table 1.

\section{Protocols and approaches used for monitoring soil profile, data estimation, and soil class formation}

\section{Methodology for soil auguring and data estimation}

Soil mapping was conducted by auguring up to $100 \mathrm{~cm}$ soil profile depth. The field was divided into nine transects along the main slope with $50 \mathrm{~m}$ distances between transects (T2, T3, T4, T5, T6, T7, and T8) with a $25 \mathrm{~m}$ distance remaining on either side of the field from the first and last transects (T1 and T9). The distance between auguring points within

Table 1 Crop management practices, cultural operations for winter triticale during crop growing season

\begin{tabular}{|c|c|c|c|}
\hline Field operations/management & $\begin{array}{l}\text { Date of field operations/ } \\
\text { application/management }\end{array}$ & $\begin{array}{l}\text { Amount applied } \\
\left(\mathrm{kg} \mathrm{ha}^{-1}\right)\end{array}$ & Machinery used for operations \\
\hline \multicolumn{4}{|l|}{$\begin{array}{l}\text { Crop }=\text { Winter triticale } \\
\text { Cultivar = Lambardo } \\
\text { Previous crop }=\text { Winter barley }\end{array}$} \\
\hline \multicolumn{4}{|l|}{ Field preparation } \\
\hline Cultivation and plowing & 15.09.2019 & & Moldboard plow \\
\hline \multicolumn{4}{|l|}{ Sowing and seed rate } \\
\hline $\begin{array}{l}\text { Seeds sowed }=275 \mathrm{~m}^{-2} \\
\text { Germination rate }=95 \% \\
1000 \text { grain weight }=52 \mathrm{~g} \\
\text { Row to row dis- } \\
\text { tance }=11 \mathrm{~cm}\end{array}$ & 20.09 .2019 & $150.5\left(\mathrm{~kg} \mathrm{ha}^{-1}\right)$ & Drilling machine \\
\hline \multicolumn{4}{|l|}{ Herbicide application } \\
\hline Herold SC & 10.10.2019 & $0.30 \mathrm{~kg}$ A.I. ha ${ }^{-1}$ & Sprayer \\
\hline Pointer SX/Trimmer SX & 10.10.2019 & 20 g A.I. ha ${ }^{-1}$ & \\
\hline \multicolumn{4}{|l|}{ Nitrogen fertilizer } \\
\hline $\begin{array}{l}\text { First application } \\
\text { (Ammonium sulfate nitrate } \\
\text { 26/13) }\end{array}$ & 27.02 .2020 & $35 \mathrm{~kg} \mathrm{~N} \mathrm{ha}^{-1}$ & Broadcast method \\
\hline $\begin{array}{l}\text { Second application } \\
(\text { Urea }(46 \% \mathrm{~N})\end{array}$ & 14.03 .2020 & $78 \mathrm{~kg} \mathrm{~N} \mathrm{ha}^{-1}$ & \\
\hline Harvesting & 27.07.2020 & & $\begin{array}{l}\text { Small combined harvester for } \\
\text { row harvesting }\end{array}$ \\
\hline
\end{tabular}

*A.I active ingredient 
a transect was $15 \mathrm{~m}$, resulting in 88 sampling points. Coordinates of each soil profile were recorded with a Trimble Geo 7X Handheld GNSS System with coordinate accuracy up to $2 \mathrm{~cm}$. An auger of $100 \mathrm{~cm}$ was used to take soil samples to estimate soil texture and color (Lange et al., 2017).

Soil color was determined in the soil auger section in moist conditions using the notations for hue, value, and chroma following the Munsell soil color charts (Munsell 1994). Texture class throughout the soil profile was determined by following the standards of the Food and Agriculture Organization (Baxter, 2007). SOM content was estimated based on soil Munsell color and by considering the texture classes (Baxter, 2007). Total SOM content in $\mathrm{kg} \mathrm{m}^{-2}$ was computed for the whole soil auguring profile $(0-100 \mathrm{~cm})$ and the plow layer $(0-30 \mathrm{~cm})$ by multiplying SOM percent content with the soil mass in each soil layer. The soil mass was estimated by multiplying the volume of the soil layer by the BD assuming a fixed value of $1.4 \mathrm{t} \mathrm{m}^{-3}$ based on soil properties in the region (Heller \& Zeitz, 2012; Schweitzer \& Hierath, 2010; Twum \& Nii-Annang, 2015). Available water capacity (AWC) was estimated based on soil texture, SOM, and BD values using Pedo-transfer function tables (Lipsius, 2002; Russ \& Riek, 2011).

\section{Soil class formation and division of the field into subfields}

In most cases of the auguring points, the soil profile was subdivided into a sandy layer at the top followed by a loamy layer that extended down to $1 \mathrm{~m}$. Thus, critical factors for the variability of soil water holding capacity were the thickness of the sandy layer and the content of SOM. Based on the assumption that points with shallow sand layers and high SOM content have the highest AWC, the field was classified into subfields with variable AWC. The C3 soil class at the downslope (DS) had lower AWC (75 mm) due to the sandy texture in the soil profile compared with that of the $\mathrm{C} 1$ soil class at the upslope (US; $115 \mathrm{~mm}$ ) (Table 2, Fig. 4, and Fig. 5). Water availability and holding capacity are largely dependent on the texture of the soil profile, especially under rain-fed conditions (Libohova et al., 2018; Wang et al., 2020; Zhou et al., 2020). The following soil classes were defined: Class-1; upper boundary of the loamy layer, $<60 \mathrm{~cm}$ in the soil profile $=$ high $\mathrm{AWC}=$ high yield potential; Class-2: upper boundary of the loamy layer, $60-100 \mathrm{~cm}$ in the soil profile $=$ moderate $\mathrm{AWC}=$ moderate yield potential; Class-3: no loamy layer in the soil profile (sandy texture throughout) $=$ low $\mathrm{AWC}=$ low yield potential.

\section{Experimental design and factors}

To test the hypothesis and quantify the relationship between crop yield, soil characteristics, and environmental factors, two main factors were defined; soil class and elevation.

Table 2 Average estimated available water capacity $(\mathrm{mm})$ regarding soil classes and elevation in the field

\begin{tabular}{llll}
\hline Elevation/ Soil classes & $\begin{array}{l}\text { Downslope } \\
\text { (DS) }\end{array}$ & $\begin{array}{l}\text { Midslope } \\
\text { (MS) }\end{array}$ & $\begin{array}{l}\text { Upslope } \\
\text { (US) }\end{array}$ \\
\hline Class1 (C1) & - & 103 & 115 \\
Class2 (C2) & - & 111 & 113 \\
Class3 (C3) & 75 & - & 96 \\
\hline
\end{tabular}

Data of the biomass sampling points has been arranged with respect to classes and elevation to compute available water capacity 

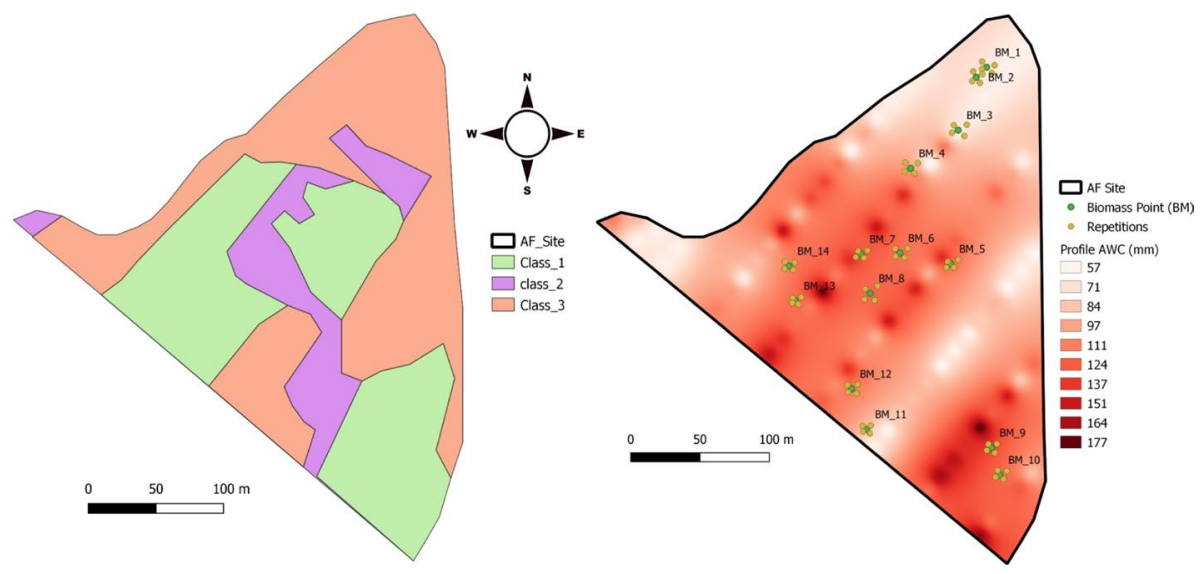

Fig. 4 Soil class distribution and soil class's polygon drawn with respect to soil classes and division of the field into subfield and soil classes. Estimated average available water capacity $(\mathrm{mm})$ profile $(100 \mathrm{~cm} \mathrm{depth})$ derived from 88 soil auguring profile data. $\mathrm{BM}=$ sampling points for biomass, and other growth and yield data

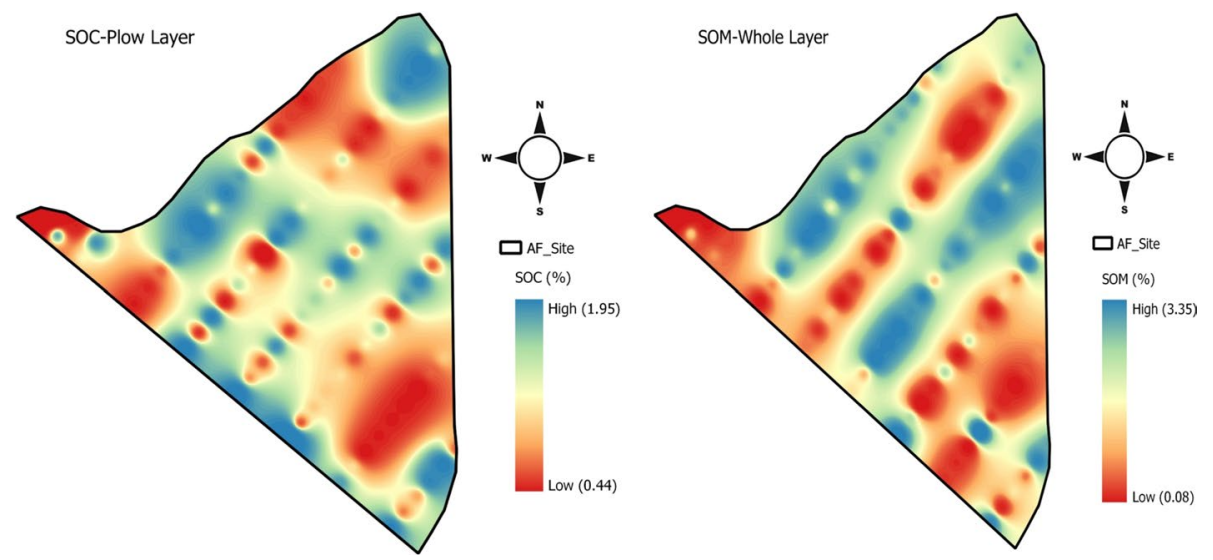

Fig. 5 In-field variability of soil organic carbon (plow layer up to $30 \mathrm{~cm}$ ) and soil organic matter (whole soil profile $100 \mathrm{~cm}$ ) is derived from 88 soil auguring profile data across the field

The distribution of sampling points with four replicates for the overall biomass and LAI are shown in Fig. 4. The sampling points were not evenly distributed within the different factor combinations (soil class $\times$ elevation). The sampling points were arranged according to study factors, i.e., soil classes and elevation $(3 \times 3=9)$, and the average of the sampling points was taken as belonging to the same treatment combination for analysis (Table 3 ). However, the unbalanced sampling design may have less statistical power and fewer test statistics as well as greater sensitivity to small departures from the equal variance assumption (homoscedasticity). A two-way factorial analysis of variance (ANOVA) was applied to assess the effect of soil class and elevation on crop yield and biomass. The parameters tested were LAI, overall biomass, plant height (PH), ear and tiller density, physiological parameters, SM at different depths, grain yield, and related attributes, which were determined at the final harvest. 
Table 3 Factors considered for monitoring of crop growth and yield

\begin{tabular}{ll}
\hline Factor 1 Soil classes & Factor 2 Elevation [m asl] \\
\hline Class 1 (C1) & Downslope (DS) $[<53.50 \mathrm{~m}]$ \\
Class 2 (C2) & Midslope (MS) $[53.51-55.30 \mathrm{~m}]$ \\
Class 3 (C3) & Upslope (US) $[>55.31 \mathrm{~m}]$ \\
\hline
\end{tabular}

Sampling points (14) were rearranged according to these factors and treatment combinations were made accordingly for statistical analysis

\section{Data sampling and monitoring}

\section{Phenology, biomass, leaf area index, physiology, soil moisture, and harvest data}

Phenology and growth stages were monitored by following the BBCH scale at all sampling points within the field (Meier, 2001). LAI was measured with the "SunScan Canopy Analyzer System" (Delta-T Devices Ltd, UK) with four replicates at BBCH-39 (end of stem elongation), and $\mathrm{BBCH}-69$ (end of anthesis, and start of grain formation) phonological stages. To monitor spatial differences in the aboveground biomass at each sampling point, biomass was destructively sampled with four replicates (Fig. 6). Biomass was cut along $50 \mathrm{~cm}$ in one row and converted into biomass per $\mathrm{m}^{2}$ based on the row distance $(12.5 \mathrm{~cm})$. Fresh biomass weight was recorded and samples were dried in an oven at $105{ }^{\circ} \mathrm{C}$ until no further weight loss occurred. Then, the dry mass of the samples was weighed and the total dry matter (TDM) was calculated by adding the dry weight of each component of the samples. Plant Height (PH) was manually recorded at the sampling points. Data for physiological parameters, such as stomatal conductance, photosynthesis, and transpiration rate, were

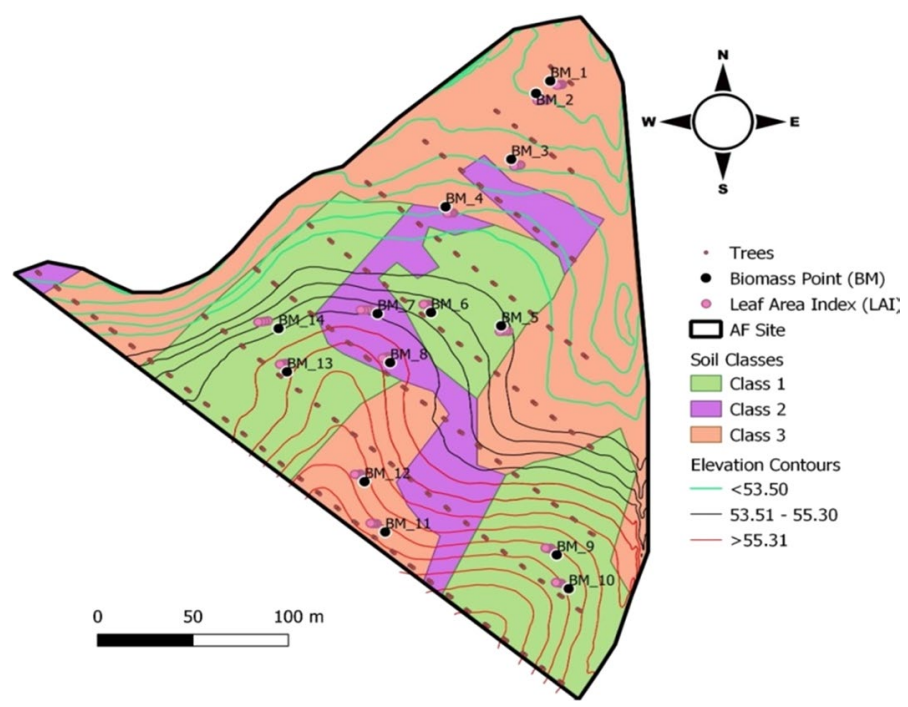

Fig. 6 Distribution of biomass and LAI sampling points across the soil classes (Class 1, Class 2, and Class 3) and elevation (DS, MS, and the US) across the field. [BM, sampling points for biomass, and other growth and yield data, LAI-AF, leaf area index-Agroforestry] 
recorded with the LI-6400/XT Portable Photosynthesis System at BBCH-39 (end of stem elongation) and $\mathrm{BBCH}-69$ (end of anthesis and start of grain formation).

To monitor and assess the variation in soil moisture (SM), the SM sensor Theta probe ML3 (Delta-T Devices) connected with the soil moisture meter HH2 was used to manually record the SM values at different depths starting from the topsoil and reaching $100 \mathrm{~cm}$ depth $(15,45,60,80$, and $100 \mathrm{~cm})$ using a soil auger to form entrance holes in the soil. Data related to final yield, biomass, and yield-related attributes were recorded at maturity from all sampling points on an area of half running meter $(50 \mathrm{~cm}$ in one row) and split into the grain, stem, and leaf components at final harvest. Each component was oven-dried at $105{ }^{\circ} \mathrm{C}$ until no further weight loss occurred and subsequently weighed again before TDM was derived. The harvest index (HI) was calculated from the subsample as the ratio between kernel weight and total dry biomass weight. Ear density and tiller density $\left(\mathrm{m}^{-2}\right)$ were determined from sampling points at the final harvest by counting the number of productive ears and tillers for ear and tiller density, respectively. These values include both productive ears and tillers (with grains and ears) and nonproductive ears and tillers (without grains and ears).

\section{Statistical analysis and interpretation}

Statistical analysis was performed using the R statistical software (R version 3.6.1, https:// www.r-project.org). Homogeneity of variance and normality were initially checked for using Levene's test and the Shapiro-Wilk test, respectively. To analyze the effect of soil class and elevation on LAI, biomass, plant height, physiology parameters (leaf photosynthetic and transpiration rates and stomatal conductance), ear and tiller density, grain yield, and yield-related traits (HI, number of grains and thousand kernel weight (TKW)) of triticale crop, a linear model for unbalanced experimental design was applied and a factorial ANOVA was performed (Speed et al., 1978; Srivastava, 2010; Wilkinson and Rogers, 2015). Significant differences between means were tested using Tukey's honestly significant difference adjustment at a 5\% level of significance. Further, Pearson correlations between soil properties and water content with the growth of winter triticale were computed.

\section{Results}

\section{Effect of in-field soil heterogeneity (soil class) and elevation on winter triticale leaf area index, plant height, and total dry matter}

Results from the ANOVA indicated significant effects of soil class, elevation, and interaction (soil class $\times$ elevation) on the LAI for all observation dates (Table 4). Generally, triticale grown on soil classes $\mathrm{C} 1$ and $\mathrm{C} 2$ performed better than that grown on C3. LAI values significantly differed between those collected from DS and those collected from US at both observation dates. Elevation had a significant effect on the LAI of triticale (Fig. 7), with DS sampling points showing lower potential and midslope (MS) and US showing moderate-to-high potential in terms of soil fertility and crop yield. Soil classes C1 and C2 were related to higher LAI values of triticale than those of C3, with C2 showing a $10.80 \%$ and $8.75 \%$ higher LAI than those of $\mathrm{C} 3$ at $\mathrm{BBCH}-39$ (end of stem elongation phase) and BBCH-69 (end of anthesis and start of grain formation), respectively (Fig. 7). In terms of 


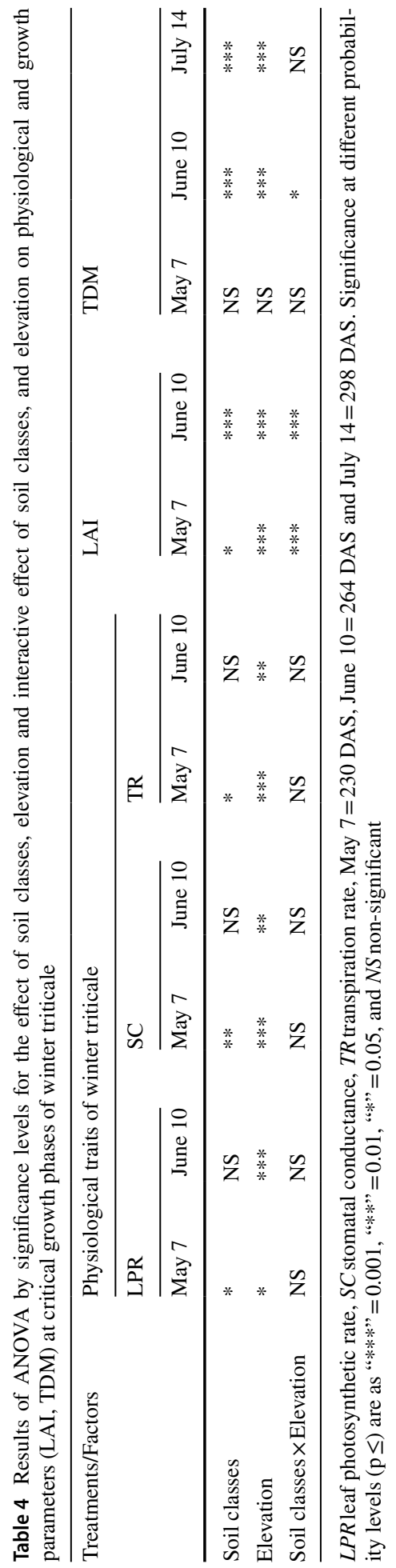




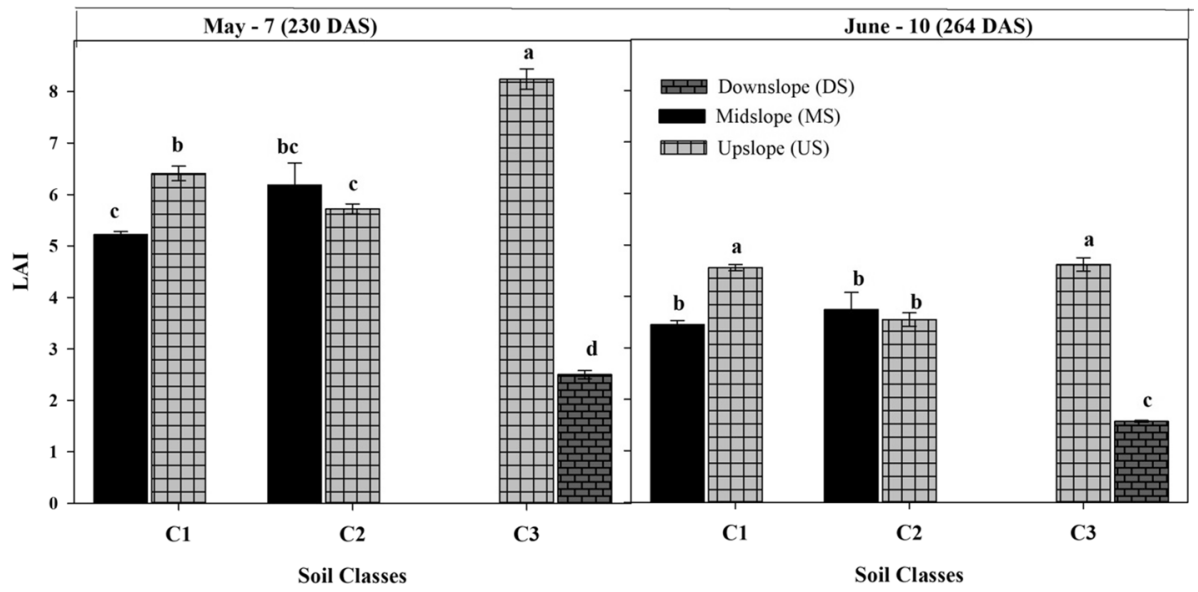

Fig. 7 Effect of soil heterogeneity (soil classes) and elevation on leaf area index of winter triticale crop at end of stem elongation phase (May 7th) and end of flowering (anthesis)/start of grain formation phase (June $\left.10^{\text {th }}\right)$

elevation, triticale located US had $\sim 63 \%$ higher LAI values at both phenological phases compared to those located DS. Additionally, LAI values of triticale located US were $16 \%$ and $15 \%$ higher than those of triticale located at MS on BBCH-39 and $\mathrm{BBCH}-69$, respectively. Figure 7 shows that soil C3 at DS had lower values of LAI (2.5 and 1.6) compared to those of all other factor combinations. The highest LAI values were observed for soil C3 at US (8.2 and 4.6) followed by C1 at US (6.2 and 4.6) during end of stem elongation and start of grain formation phases, respectively (Fig. 7).

Similar effects of soil heterogeneity and elevation on winter triticale were observed for aboveground TDM (Table 4). In-field soil heterogeneity (soil classes) and elevation had significant effects on triticale, especially when comparing soil classes $\mathrm{C} 3$ with $\mathrm{C} 1$ and US with DS (Fig. 8). Meanwhile, significant interactions were found for biomass during flowering with $48 \%$ higher TDM for the $\mathrm{C} 1$ soil class at US than that of the C3 soil class at DS. However, on 230 DAS (May 7th), biomass did not differ significantly between soil classes and elevation. The difference between triticale at DS and US in soil C3 was pronounced, with 53\% higher TDM for US. While on 264 DAS (June 10th), triticale growing on soil C1 produced 3\% and 33\% higher TDM (13 $\left.102 \mathrm{~kg} \mathrm{ha}^{-1}\right)$ than C3 (8549 $\left.\mathrm{kg} \mathrm{ha}^{-1}\right)$ and C2 $\left(8784 \mathrm{~kg} \mathrm{ha}^{-1}\right)$, respectively, while triticale grown at US had 59\% and 10\% higher TDM $\left(11689 \mathrm{~kg} \mathrm{ha}^{-1}\right)$ than those grown at DS $\left(4730 \mathrm{~kg} \mathrm{ha}^{-1}\right)$ and MS (10 $\left.535 \mathrm{~kg} \mathrm{ha}^{-1}\right)$, respectively (Fig. 8).

The strength of the interactive effect of soil classes and elevation on TDM obtained on June 10 followed the order C1US $>$ C3US $>$ C1MS $>$ C2MS $>$ C2US $>$ C3DS. A similar pattern was identified for TDM collected at the maturity stage (BBCH-89), where soil classes and elevation had a significant effect on TDM. Triticale in soil class C1 had 19\% higher TDM (14 $\left.786 \mathrm{~kg} \mathrm{ha}^{-1}\right)$ than those in C3 $\left(12016 \mathrm{~kg} \mathrm{ha}^{-1}\right)$, while triticale US had $67 \%$ greater TDM (17 $\left.840 \mathrm{~kg} \mathrm{ha}^{-1}\right)$ than those DS (5 $\left.873 \mathrm{~kg} \mathrm{ha}^{-1}\right)$. TDM patterns observed at maturity were similar to those observed at previous phenological phases and followed the order C3US $>$ C2US $>$ C1US $>$ C2MS $>$ C1MS $>$ C3DS. Biomass results showed that soil classes $\mathrm{C} 1$ and $\mathrm{C} 2$ produced relatively high TDM compared to that of $\mathrm{C} 3$ while triticale at US had a higher TDM than those MS and DS (Fig. 8). Temporal differences in the 


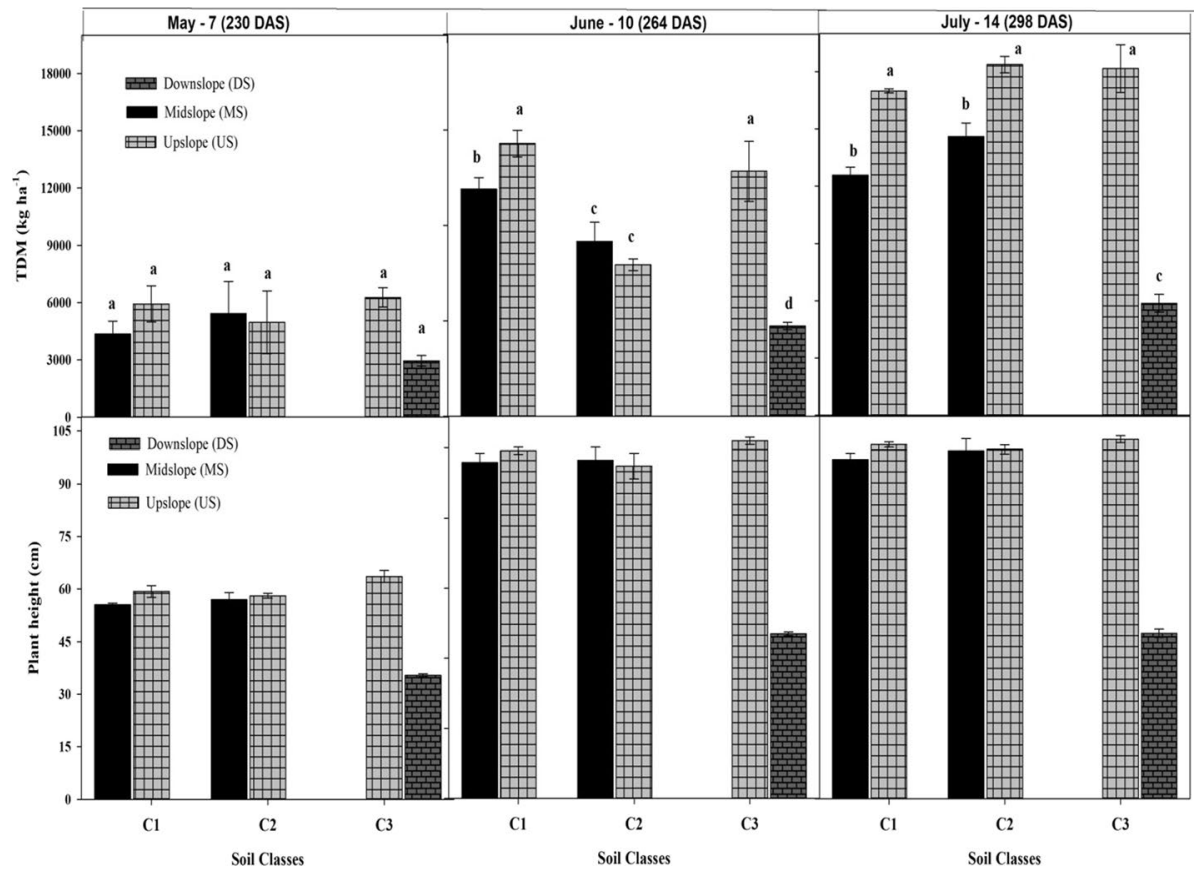

Fig. 8 Temporal variations in above ground total dry matter (TDM) and plant height of winter triticale as related to soil heterogeneity (soil classes) and elevation classes

development and growth of triticale were indicated by a 50\% higher TDM $\left(10144 \mathrm{~kg} \mathrm{ha}^{-1}\right)$ being obtained on BBCH-69 (June 10th) compared to that for BBCH-39 (4 $986 \mathrm{~kg} \mathrm{ha}^{-1}$ ).

Plant height (PH) also followed a similar pattern to TDM, with significant soil class and elevation effects. Higher PHs were observed in soil classes C1 and C2 than those in C3 at all sampling dates. Similarly, higher PHs were recorded at US and MS while plants at DS always had lower heights considering the temporal comparison during crop growth phases. Triticale grown in soil class $\mathrm{C} 1$ had $14 \%, 24 \%$, and $25 \%$ higher $\mathrm{PH}$ than those grown in soil C3 on 230, 264 and 298 DAS respectively. Triticale grown at US had 41\%-54\% higher crop height than those at DS at all recorded periods, showing significant differences due to elevation. Soil class C3 produced the highest and lowest PHs at US and DS, respectively when the interactions of factors were compared. The interactive effects of soil class and elevation on $\mathrm{PH}$ were found to be in the following order: C3US $>\mathrm{C} 1 \mathrm{US}>\mathrm{C} 2 \mathrm{US}>\mathrm{C} 2 \mathrm{MS}>$ $\mathrm{C} 1 \mathrm{MS}>\mathrm{C} 3 \mathrm{DS}$; C3US > C1US > C2MS > C1MS > C2US > C 3DS; and C3US > C1US > C1 MS $>$ C2US $>$ C2MS $>$ C3DS for 230 DAS (May 7th), 264 DAS (June 10th), and 298 DAS (July 14th), respectively (Fig. 8). Temporal analysis of PHs also showed significant variation (40\% higher at harvest compared to 230 DAS.

\section{The effect of soil classes and elevation on the leaf photosynthetic rate, stomatal conductance, and transpiration rate of winter triticale}

Triticale's physiological parameters showed significant differences between different soil classes and elevation levels $(\mathrm{p}<0.05)$. Leaf photosynthetic rate $\left(\mu \mathrm{mol} \mathrm{CO} \mathrm{Cm}^{-2} \mathrm{~s}^{-1}\right)$ of 
triticale grown in soil class $\mathrm{C} 1$ (13.8 and $\left.7.5 \mu \mathrm{mol} \mathrm{CO} \mathrm{m}^{-2} \mathrm{~s}^{-1}\right)$ and $\mathrm{C} 2(15.1$ and $6.7 \mu \mathrm{mol}$ $\mathrm{CO}_{2} \mathrm{~m}^{-2} \mathrm{~s}^{-1}$ ) showed higher values than those grown in soil $\mathrm{C} 3(11.9$ and $6.0 \mu \mathrm{mol} \mathrm{CO}$ $\mathrm{m}^{-2} \mathrm{~s}^{-1}$ ) for May 7th (230 DAS) and June 10th (264 DAS), respectively. Significant differences were observed at US, where the leaf photosynthetic rate was $21.5 \%$ and $54.2 \%$ higher than those observed at DS on May 7th and June 10th, respectively. Similarly, the photosynthetic rate of plants at MS showed significant differences compared to those at DS. The interactive effects of soil classes and elevation on leaf photosynthetic rate followed the order C2MS $>$ C1MS $>$ C2US $>$ C3US $>$ C1US $>$ C3DS and C3US $>$ C1US $>$ C2 MS $>$ C1MS $>$ C2US $>$ C3DS for May 7th (230 DAS) and June 10th (264 DAS), respectively. Triticale grown in soil class $\mathrm{C} 1$ and $\mathrm{C} 2$ at US and MS had higher leaf photosynthetic rates than those grown in soil C3, particularly at DS. A 50\% higher leaf photosynthetic rate was recorded for May 7 th $\left(13.6 \mu \mathrm{mol} \mathrm{CO} \mathrm{m}^{-2} \mathrm{~s}^{-1}\right)$ than for June 10 th $(6.9 \mu \mathrm{mol} \mathrm{CO}$ $\mathrm{m}^{-2} \mathrm{~s}^{-1}$ ), as there was a reduction in stomatal conductance due to drought conditions leading up to June 10th. There was $<5 \%$ SM recorded at both soil depths $(15$ and $45 \mathrm{~cm}$ ) on June 10th (Fig. 9).

As stomatal conductance strongly affects photosynthetic rates, similar patterns were shown for the different soil classes and elevations (Table 4). Triticale grown in C3US had higher stomatal conductance $\left(0.17\right.$ and $\left.0.13 \mathrm{mmol} \mathrm{H}_{2} \mathrm{O} \mathrm{m}^{-2} \mathrm{~s}^{-1}\right)$ than C2US on May 7 th than on June 10th, respectively. Triticale grown on US had significantly higher stomatal conductance (46\% and 52\%) than that DS on May 7th and June 10th, respectively. The interactive effect of soil classes and elevation followed the order C1MS $>\mathrm{C} 2 \mathrm{MS}>\mathrm{C} 3 \mathrm{U}$ $\mathrm{S}>\mathrm{C} 1 \mathrm{US}>\mathrm{C} 2 \mathrm{US}>\mathrm{C} 3 \mathrm{DS}$ and C3US $>\mathrm{C} 1 \mathrm{US}>\mathrm{C} 2 \mathrm{US}>\mathrm{C} 1 \mathrm{MS}>\mathrm{C} 2 \mathrm{MS}>\mathrm{C} 3 \mathrm{DS}$ at 230 and 262 DAS, respectively (Fig. 9). Stomatal conductance decreased by $34 \%$ ( $0.09 \mathrm{mmol}$ $\left.\mathrm{H}_{2} \mathrm{O} \mathrm{m}^{-2} \mathrm{~s}^{-1}\right)$ in plants at the end of the flowering phase and start of the grain formation phase (June 10th) compared to those at end of the stem elongation phase $\left(0.14 \mathrm{mmol} \mathrm{H}_{2} \mathrm{O}\right.$ $\mathrm{m}^{-2} \mathrm{~s}^{-1}$ ) due to prevailing drought conditions as less than 5\% SM was present on June 10th at both soil depths $(15$ and $45 \mathrm{~cm}$ ). The transpiration rate at both sampling dates showed similar patterns to stomatal conductance, wherein soil classes and elevation were both found to have a significant effect on transpiration rate on May 7 th, while the only elevation was found to have a significant effect on June 10th. This effect was particularly significant for soil C3US plants due to advantages in elevation as a result of contour depression. Soil class $\mathrm{C} 1$ plants had a $18 \%$ and $11 \%$ higher $\left(1.81\right.$ and $\left.1.28 \mathrm{mmol}_{2} \mathrm{O} \mathrm{m}^{-2} \mathrm{~s}^{-1}\right)$ transpiration rate compared with those in C3. Similarly, US and MS plants in soil C1 had significantly higher transpiration rates than those in soil C3 at both data sampling dates (May 7th and June 10th), while transpiration rates at US are being 33\% and $51 \%$ higher than those DS on May 7th and June 10th, respectively. C1US had better crop growth conditions than soil C3DS (Fig. 9). Similarly, significantly higher values of transpiration $(+26 \% ; 1.65 \mathrm{mmol}$ $\left.\mathrm{H}_{2} \mathrm{O} \mathrm{m}^{-2} \mathrm{~s}^{-1}\right)$ were obtained for May 7 th than for June 10th $\left(1.22 \mathrm{mmol} \mathrm{H}_{2} \mathrm{O} \mathrm{m}^{-2} \mathrm{~s}^{-1}\right)$ as the peak vegetative growth phase and high physiological activities occurred in May. The interactive effects followed the order C1MS $>$ C3US $>$ C2MS $>$ C1US $>$ C2US $>$ C3DS and $\mathrm{C} 3 \mathrm{US}>\mathrm{C} 1 \mathrm{US}>\mathrm{C} 2 \mathrm{US}>\mathrm{C} 1 \mathrm{MS}>\mathrm{C} 2 \mathrm{MS}>\mathrm{C} 3 \mathrm{DS}$ for May 7th and June 10th, respectively.

\section{Temporal and spatial patterns of soil moisture content at critical growth phases of winter triticale crop}

SM measurements were strongly influenced by the occurrence of only $30 \mathrm{~mm}$ of rainfall during the first eleven days of March then there is no rainfall event occurred during March, while April $(6 \mathrm{~mm})$ and May $(27 \mathrm{~mm})$ were also extremely dry, coinciding with 


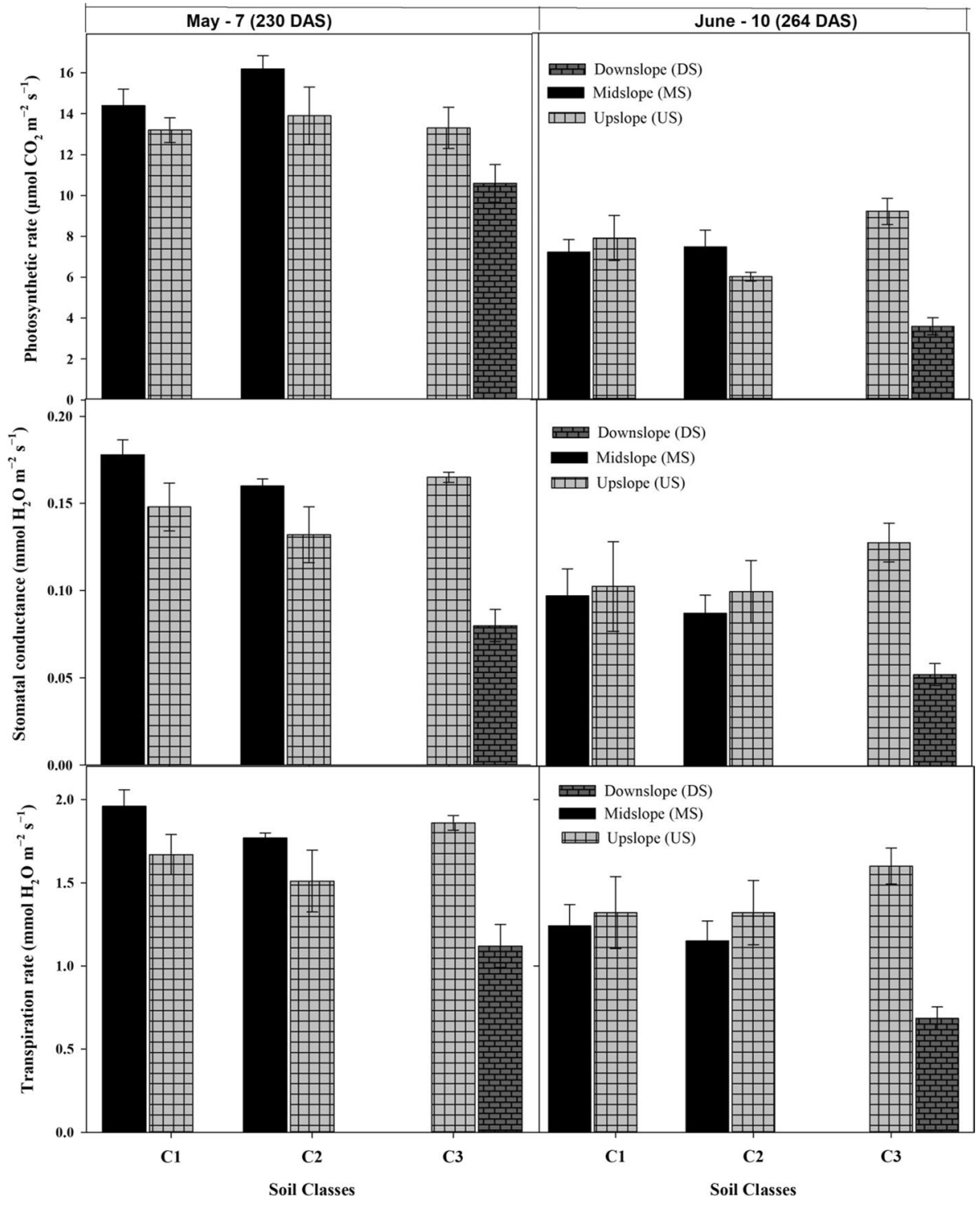

Fig. 9 Effect of soil heterogeneity (soil classes) and elevation classes on crop physiological parameters like photosynthetic rate $\left(\mu \mathrm{mol} \mathrm{CO} \mathrm{Cm}^{-2} \mathrm{~s}^{-1}\right)$, stomatal conductance $\left(\mathrm{mmol} \mathrm{H} \mathrm{O} \mathrm{m}^{-2} \mathrm{~s}^{-1}\right)$, and transpiration rate $\left(\mathrm{mmol} \mathrm{H}_{2} \mathrm{O} \mathrm{m}^{-2} \mathrm{~s}^{-1}\right)$ of winter triticale recorded at $\mathrm{BBCH}-39$ and $\mathrm{BBCH}-69$ stages

the critical crop growth phases. The effects of the different soil classes on the SM content at 15 and $45 \mathrm{~cm}$ soil depth were significant for all SM measurement dates, while the effects of elevation were also significant for 230 (May 7th) and 264 DAS (June 10th) (Table 5). The interactive effects were also significant for measurements taken on May 7th only. The mean SM also indicated temporal differences of $6.5 \mathrm{Vol} \%, 3.7 \mathrm{Vol}$ $\%$, and $11.4 \mathrm{Vol} \%$ on May 7th (230 DAS), June 10th (264 DAS), and July 14th (298 DAS), respectively (Fig. 10). The higher SM content at maturity might be due to lower 
Table 5 Monthly rainfall ( $\mathrm{mm})$ and crop growth phases of winter triticale

\begin{tabular}{|c|c|c|c|c|c|c|c|c|c|c|c|}
\hline Months & Sep & Oct & Nov & Dec & Jan & Feb & Mar & Apr & May & Jun & Jul \\
\hline $\begin{array}{l}\text { Rainfall } \\
(\mathrm{mm})\end{array}$ & 72 & 59 & 61 & 31 & 38 & 64 & 30 & 6 & 27 & 74 & 41 \\
\hline Crop growth phases & G & LD & LD \& T & - & - & - & $\mathrm{T}$ & SE & $\mathrm{B} \& \mathrm{H}$ & $\mathrm{F} \& \mathrm{GF}$ & $\mathrm{R} \& \mathrm{H}$ \\
\hline
\end{tabular}

* $G$ germination, $L D$ leaf development, $T$ tillering, $S E$ stem elongation, $B$ booting, $H$ heading, $F$ flowering, $G F$ grain formation, $R \& H$ ripening and harvest

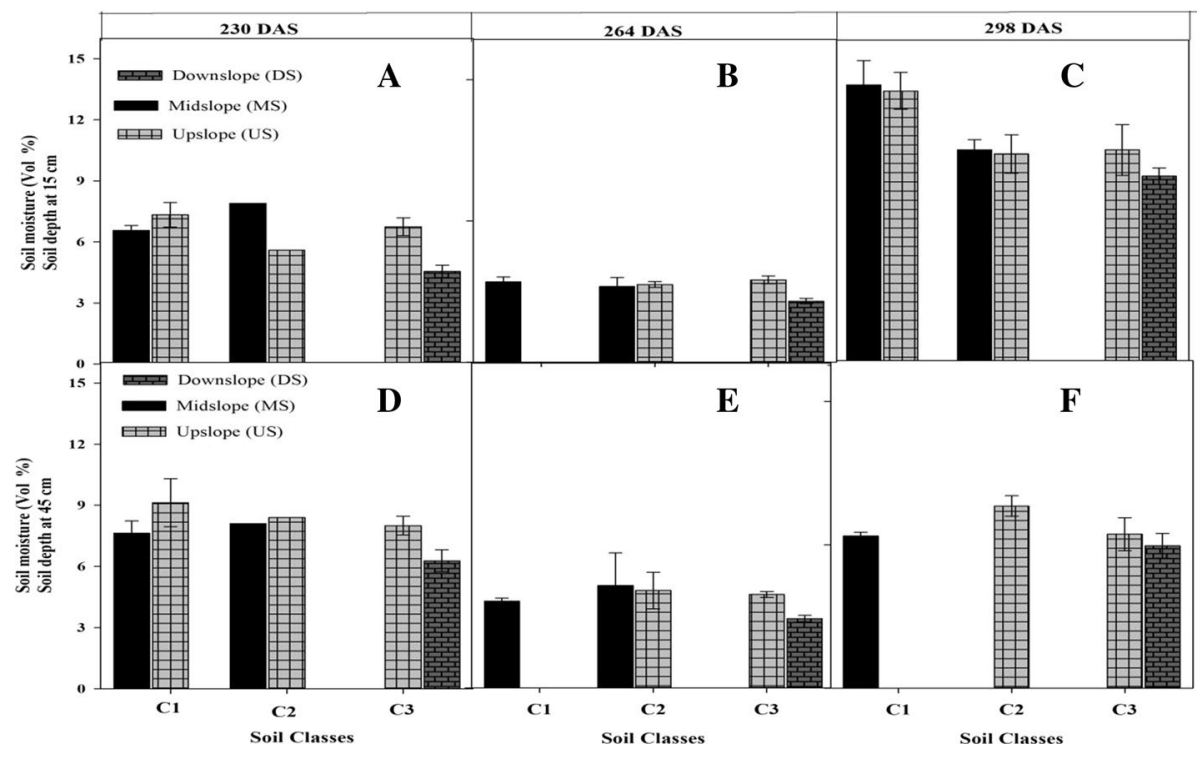

Fig. 10 Temporal variation in soil moisture (Vol \%) at soil depths of $15 \mathrm{~cm} \mathrm{A,} \mathrm{B,} \mathrm{C} \mathrm{and} 45 \mathrm{~cm} \mathrm{D,}$ $\mathbf{E}, \mathbf{F}$ at different critical crop growth phases (230 DAS = May 7th (BBCH- 39, end of stem elongation), 264 DAS = June 10th (BBCH-69 end of anthesis and start of grain formation) and 298 DAS = July 14 th $=\mathrm{BBCH}-89$ (fully ripened crop stage). Missing bars where sampling was not possible due to hard soil and rock in layers as auguring was made manually

crop water uptake and higher rainfall during June $(74 \mathrm{~mm})$, while lower SM content at early phases might be due to high water demand at peak vegetative growth phases and grain formation and the extremely low amounts of rainfall in April and May (prevailing drought conditions). Soil classes $\mathrm{C} 1$ and $\mathrm{C} 2$ had significantly higher SM content (7 Vol \% and 6.8 Vol \%; $24 \%$ and $21 \%$, respectively) than soil C3, while there was $33 \%$ greater SM content at a $15 \mathrm{~cm}$ soil depth both US and MS compared to DS on May 7th. Similarly, soil class C2 had higher SM content (11\%) compared to C3, and MS soil also had $23 \%$ higher SM content than DS on June 10th. Similarly, the SM content at crop maturity phases was $28 \%$ and $23 \%$ higher in soil $\mathrm{C} 1$ than in C3, while both US and MS SM content was $22 \%$ higher than that DS on July 14th, respectively (Fig. 10). SM contents at $45 \mathrm{~cm}$ soil depth showed similar effects of elevation and soil class on moisture levels. Soil class C1 had a SM content of 8.4 Vol \% and soil C3 had a SM content of $6.8 \mathrm{Vol} \%$; likewise, soil US had 26\% higher SM content than DS (6.3 Vol $\%)$ at 230 DAS. Soil classes and elevation had a significant effect on SM content, with 
Table 6 Results of ANOVA by significance levels for the effect of soil classes, elevation and interactive effect of soil classes, and elevation classes on grain yield and yield components of winter triticale

\begin{tabular}{lllllll}
\hline Treatments/Factors & \multicolumn{2}{l}{ Yield and related traits } \\
\cline { 2 - 6 } & GY & HI & $\begin{array}{l}\text { Ear density } \\
\left(\mathrm{m}^{-2}\right)\end{array}$ & $\begin{array}{l}\text { Tiller density } \\
\left(\mathrm{m}^{-2}\right)\end{array}$ & $\begin{array}{l}\text { Number of } \\
\text { grains }\left(\mathrm{m}^{-2}\right)\end{array}$ & TKW \\
\hline Soil classes & NS & NS & $* *$ & $* *$ & NS & $* * *$ \\
Elevation & $* * *$ & $* * *$ & $*$ & $*$ & $* * *$ & $* * *$ \\
Soil classes $\times$ Elevation & $*$ & $*$ & NS & NS & $*$ & NS \\
\hline
\end{tabular}

$G . Y=$ grain yield, $H I=$ harvest index, $T K W=$ thousand kernel weight

Significance at different probability levels $(\mathrm{p} \leq)$ are as $" * * * *=0.001$, “*** $=0.01$, “*” $=0.05$, NS $=$ nonsignificant

soil C2 having 223\% higher SM content (4.9 Vol \%) than soil C3; similarly, the MS soil had 24\% higher SM content than DS soil (3.41 Vol \%) at 264 DAS (June 10th). The SM content at the crop maturity phase at a $45 \mathrm{~cm}$ soil depth was not significant. The mean SM contents of 7.9 Vol \%, $4.2 \mathrm{Vol} \%$, and $7.7 \mathrm{Vol} \%$ were found at 230, 264, and 298 DAS, respectively.

\section{The effect of in-field soil heterogeneity (soil classes) and elevation on the grain yield and yield-related attributes of winter triticale}

A point-based sampling of grain yield showed considerable differences in triticale yield between different elevations and soil classes. Elevation had a significant effect on grain yield while soil classes did not have a significant effect due to higher standard error (Table 6). The interactive effects showed a clearer picture as plants grown on C3US produced the highest yields (Fig. 11). Triticale in soil class C1 had a $10 \%$ higher grain yield (5 $485 \mathrm{~kg} \mathrm{ha}^{-1}$ ) than those in soil class C3 (4 $916 \mathrm{~kg} \mathrm{ha}^{-1}$ ), while triticale grown on US had $88 \%$ and $43 \%$ higher grain yields $\left(7414 \mathrm{~kg} \mathrm{ha}^{-1}\right)$ than those on DS (906 $\mathrm{kg} \mathrm{ha}^{-1}$ ) and MS (4 $196 \mathrm{~kg} \mathrm{ha}^{-1}$ ), respectively. Triticale grown on MS had $78 \%$ higher grain yield than those on DS. Triticale grown at DS had the lowest yield. HI is an important indicator showing the proportion of economic yield and total aboveground dry matter. The HI results followed the same pattern as those of grain yield. Triticale in soil class $\mathrm{C} 1$ had a $\mathrm{HI}$ that was only $10 \%$ higher (36.5) than those in soil class C3 (32.8). Due to a high standard error (6.66) in soil C3, results were not significant among soil classes. Different elevations showed higher differences among DS, MS, and US plants, where the HI at US (42.4) was $63 \%$ and $21 \%$ higher than those DS (15.9) and MS (33.5), respectively, while the HI at MS was also 53\% higher than that DS. Results of the interactive effects showed the same pattern as those of yield, wherein the HI at soil class C3 was highest and lowest for US and DS, respectively (Fig. 11).

The results of ear and tiller densities contrasted with those provided above. While soil classes and elevation showed significant effects, their interactions were not significant. The number of tillers and ears produced DS and in soil C3 was significantly higher than those of other factor combinations. Ear and tiller densities were $19 \%$ and $20 \%$ higher (584 and $632 \mathrm{~m}^{-2}$ ) at soil class C3 than those of soil C1 (470 and $\left.505 \mathrm{~m}^{-2}\right)$, respectively. Similarly, plants DS also had higher (21\% and 23\%) ear and tiller densities 

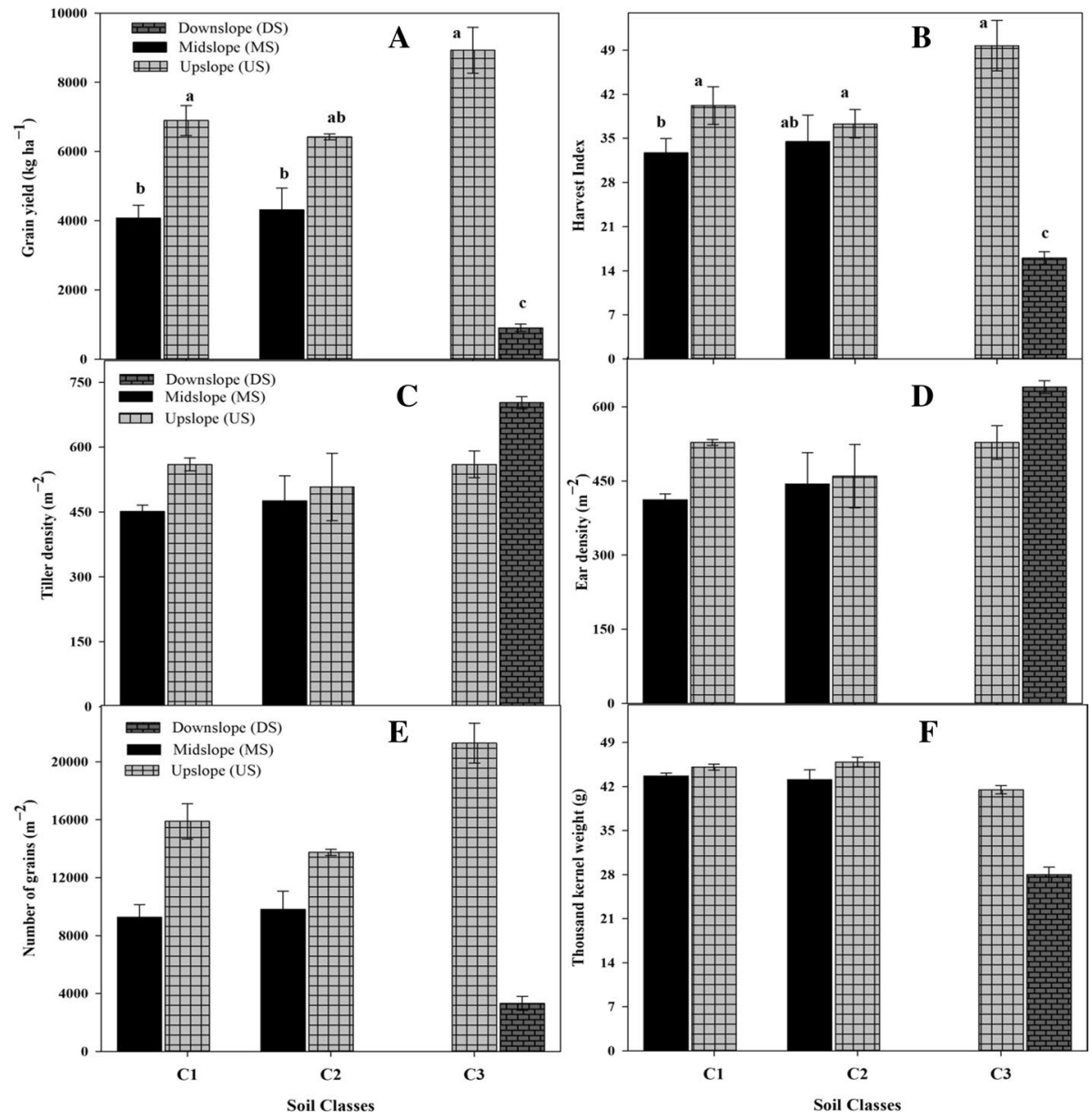

Fig. 11 Effect of infield soil heterogeneity (soil classes) and elevation on grain yield $\mathbf{A}$, harvest index $\mathbf{B}$, tiller density $\mathbf{C}$, ear density $\mathbf{D}$, number of grains $\mathbf{E}$, and thousand kernel weight $\mathbf{F}$ at final harvest from the point-based analysis

(640 and $703 \mathrm{~m}^{-2}$ ) than those US $\left(505\right.$ and $543 \mathrm{~m}^{-2}$ ), respectively. The interactive effect of soil classes and elevation is shown in Fig. 11. Results related to the number of grains and TKW showed significant differences between elevations for both soil classes and elevations. US plants produced $80 \%$ and $43 \%$ more grains $\left(16976 \mathrm{~m}^{-2}\right)$ than those DS and MS (3 319 and $9550 \mathrm{~m}^{-2}$ ), respectively. Similarly, MS plants produced a significantly higher number of grains $(65 \%)$ than those DS. Interactions followed the order $\mathrm{C} 3 \mathrm{US}>\mathrm{C} 1 \mathrm{US}>\mathrm{C} 2 \mathrm{US}>\mathrm{C} 2 \mathrm{MS}>\mathrm{C} 1 \mathrm{MS}>\mathrm{C} 3 \mathrm{DS}$, and plants US in either soil C1, C2, or $\mathrm{C} 3$ produced the highest number of grains. A $22 \%$ higher TKW $(44.4 \mathrm{~g})$ was recorded in soil C1 and C2 compared to that in soil C3 (34.7 g). Similarly, US and MS plants had $37 \%$ and $36 \%$ higher TKWs (44.2 and $43.4 \mathrm{~g}$ ) than those DS (28.0 g), respectively. Overall, plants US in soil C1 and C2 had higher TKW than others, particularly compared to that of soil C3DS (Fig. 11). The results showed that high triticale grain yield 
and positive attributes occurred at soil $\mathrm{C} 1$ compared to those at soil $\mathrm{C} 3$ and, similarly, higher grain yield was obtained US rather than DS.

\section{Discussion}

\section{In-field soil heterogeneity, elevation, and properties across the field}

In precision farming, knowledge regarding in-field soil heterogeneity is crucial for understanding and managing crops for appropriate soil utilization and efficient use of inputs. Sub-division of a field into soil classes/zones is a desirable strategy for understanding infield soil heterogeneity and to assist in decision-making regarding the effective utilization of inputs, however soil information at field scale with adequate spatial resolution is scarce (Chen et al., 2020, 2021; Nawar et al., 2017; Patzold et al., 2008). Although many studies have investigated the effects of in-field soil heterogeneity and topography on different crops (e.g. maize and soybean) and yield (Chen et al., 2021; Ferrara et al., 2010; Hao et al., 2010; Quiroga et al., 2006; Whitman et al., 1985), few have investigated the effect on triticale grown under temperate climate conditions. The results of this study confirmed that large variations in soil properties at the field scale do exist in undulating landscapes. Significant differences in soil properties (texture, SOM, and AWC) were observed across elevation classes at US and DS positions for three soil classes (Fig. 4 and Fig. 5). A sandy topsoil texture was dominant throughout the field, while subsoil properties varied (silty loam, sandy clay, and fine sandy loam). As the thickness of the sandy top layer was also variable, the depth of the loamy layer was considered as a proxy to quantify differences in AWC and to define three soil classes (Heller \& Zeitz, 2012; Schweitzer \& Hierath, 2010; Twum \& Nii-Annang, 2015). There were spatial differences between AWC (57-177 mm) and SM stored in soil profiles across the field, confirming the heterogeneous nature of the soils (Fig. 4 and Table 2).

There were differences between soil classes $\mathrm{C} 1$ and $\mathrm{C} 3$ as, in $\mathrm{C} 3$, there was no loamy layer down to $100 \mathrm{~cm}$ soil depth (C3), while a loamy layer was present at a depth above $60 \mathrm{~cm}$ in soil class $\mathrm{C} 1$. There was also significantly higher water content present in soil class C1 compared to soil class C3 (Figs. 4 and 10). Water availability and water holding capacity are largely dependent on the depth of the loamy layer in the soil profile, especially under rain-fed conditions (Libohova et al., 2018; Wang et al., 2020; Zhou et al., 2020). There was an almost $11 \%$ difference in elevation $(51.5-57.7 \mathrm{~m})$ between the DS and US elevation classes within the field (Fig. 1). Thus, elevation was considered as an important factor for investigation, to observe the effects of elevation on crop growth and biomass production (Table 3 and Fig. 6). As spatial variability in SOM, texture, and elevation lead to variation in water and nutrient supply, this ultimately leads to in-field heterogeneity of crop growth and yield (Zhang et al., 2014). Recently, Metwally et al., (2019) established an effective precision management strategy for the evaluation of spatial variability across a field like precise (site-specific) nutrient management to maximize crop production. It is a precise soil site-specific nutrient management strategy for the farmers for better decision management and resource use efficiency.

Results of SM (Vol \%) measurements collected during critical crop growth phases at different soil depths $(15$ and $45 \mathrm{~cm})$ revealed the spatial variation and significant differences between soil classes and elevation (Fig. 10) due to variation in soil properties, such as SOM, depth to the loamy layer, and elevation across the field. Differences in soil texture 
lead to a variation in water holding capacity while variation in elevation within a field also affects the nutrient and water supply, especially under rain-fed conditions (Hao et al., 2010; Libohova et al., 2018; Zhang et al., 2014). SM measurements also confirmed the spatial variability and heterogeneity within the field as differences were observed between soil classes $\mathrm{C} 1-\mathrm{C} 3$, while the soil at US position also had significantly higher moisture content compared to DS in the top soil layer $(15 \mathrm{~cm})$. This was, firstly, due to differences in the elevation, which led to differences in water holding capacities (Hao et al., 2010; Huang et al., 2008; Kravchenko et al., 2003). However, in the case of the entirely sandy soil class C3 at US position, which had consistently higher SM than at DS, other processes like the lateral sub-surface flow from the surrounding areas, may be responsible. Thus, there was a significant interaction between elevation and soil classes that causes in-field heterogeneity in soil moisture. In addition, as soil class C3 at US position was located in the small depression within the convex slope, it was associated with higher SOM content, which affects soil aggregation and leads to improved water retention capacity and nitrogen supply, which, in turn, impacts crop growth and yield (Kumhálová et al., 2011; Ladoni et al., 2016; Poffenbarger et al., 2020). In general, the sampling points located at DS had lower yield potential as soils in convexities at higher elevations (US), because they accumulate fine sandy topsoil transported from higher elevations, thus, water retention capacity is lower (sandy soils) (Dercon et al., 2006; Kravchenko \& Bullock, 2000).

\section{The effect of in-field soil heterogeneity and elevation on the growth, dry biomass, and physiological traits of winter triticale}

The results revealed that the different soil and elevation classes had significant effects on most of the growth parameters of triticale. Triticale growing in soil class $\mathrm{C} 1$ generally had higher biomass yields than those in soil C3. The same was true for LAI, TDM, and PH. Only for TDM obtained on May 7th, there was no significant effect of the soil classes found because the drought stress was lower than that in the later phenological stages and there was higher variability (high standard error) in the biomass sampled. However, the effect of elevation was significant on all parameters in all observation periods, with lower values obtained at the DS position compared to those obtained at US. The results showed that plants at DS had lower TDM and yield potential compared to those at MS and US (Fig. 8). Physiological parameters recorded on May 7th and June 10th also confirmed the differences in growth conditions between the soil classes and, in particular, between elevation classes within the field. Physiological parameters were significantly positively associated with TDM, LAI, and PH, and higher photosynthetic rate and stomatal conductance in elevation class US led to higher biomass production than at DS.

The variation of triticale growth due to soil classes and elevation can partly be explained by the SM content at 15 and $45 \mathrm{~cm}$ soil depths recorded at different critical crop development phases combined with the transpiration rates. SM for soil class $\mathrm{C} 1$ was usually higher than for C3, except for the C3 soils located at US (Fig. 10). This was also confirmed by the higher transpiration rates of triticale growing in soil class C3 at US compared to DS. As the soil class C3 at US was located in a slight depression within the convex slope, the better water supply to triticale in soil class $\mathrm{C} 3$ at US could be explained by a lateral flux of water into the depression. The average SM in the top layers $(0-45 \mathrm{~cm})$ overall sampling points showed a significantly strong association with the LAI, TDM, and PH of the triticale crop especially during end of stem elongation (May 7th) and end of flowering and start of grain formation phases (June 10th) (ASM_TL_1 and ASM_TL_2 in Fig. 12). However, ASM 


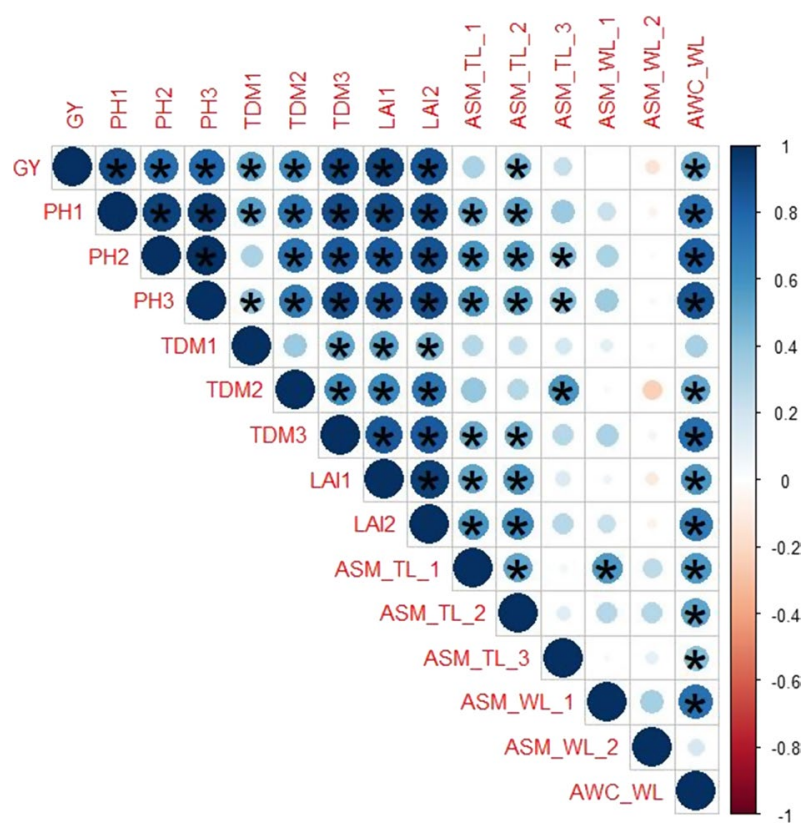

Fig. 12 Correlation of different parameters like growth (TDM, LAI, and PH) and yield-related attributes vs average soil moisture in top layers $(0-45 \mathrm{~cm})$ and whole soil profile $(0-100 \mathrm{~cm})$ at different critical growth phases for studied factors (soil class and elevation). The blue shade shows a positive correlation and the pink shade shows a negative correlation. The areas of circles show the absolute value of the corresponding correlation coefficients tested at the *0.05 significance level. The size of the circle shows how traits are associated with each other. * indicates significant $(\mathrm{P}<0.05)$ and without sign $(*)$ indicates non-significant $(\mathrm{P} \geq 0.05)$. ASM Average soil moisture, TL top layer $(0-45 \mathrm{~cm}), W L$ whole layer $(0-100 \mathrm{~cm}), A W C_{-} W L$ available water capacity in whole soil profile $(100 \mathrm{~cm}), L A I$ leaf area index, GY grain yield, TDM total dry matter, and $P H$ Plant height. [1, 2, and 3 digit numbers are mentioned with parameters like ASM_TL_1, ASM_ WL_1, TDM_1, TDM_2, TDM_3 etc. The numbers 1, 2, and 3 are the observations made at different dates 230 DAS (May 7th), 264 DAS (June 10th), and 298 DAS (July 14th), respectively] (Color figure online)

at maturity (July 14th) had no effect as the crop had almost reached physiological maturity and sufficient rainfall $(>60 \mathrm{~mm}$ ) only occurred at the end of June and beginning of July (Table 5 and Fig. 10). In addition, biomass production and growth of triticale (TDM2 and TDM3) had a stronger positive relationship with AWC of the soil profile $(100 \mathrm{~cm})$ of biomass sampling points (Fig. 12). Evidently, differences in texture between elevation and soil classes, especially at the upper boundary of the loamy layer, led to variations in the water retention potential and in water availability to the crop, which ultimately affected plant growth and biomass production. Thus, differences in elevation and terrain affected the water and nutrients available to the crop. Previous studies related to in-field soil heterogeneity and elevations have confirmed the effect on crop growth and yield (Kravchenko et al., 2003; Kumhálová et al., 2011). Crop growth and biomass of corn and soybean in an undulating field (sandy loam to clay loam) at topographical depressions increase due to favorable hydrological and edaphic factors compared to other areas within the same field under humid continental climatic conditions (Beehler et al., 2017; Kravchenko \& Bullock, 2000). Although many studies have investigated the effects of in-field soil heterogeneity and topography on crops like maize and soybean, none have been conducted regarding 
triticale but available for other crops (Chen et al., 2021; Ferrara et al., 2010; Hao et al., 2010; Quiroga et al., 2006; Whitman et al., 1985).

\section{The effect of in-field soil heterogeneity and elevation on grain yield and related attributes of winter triticale crop grown in an intensively cropped hummocky landscape}

In this study, significant effects of elevation and soil classes on grain yield and yield components were found. There was high variability in grain yield data, especially in the soil class C3 (high standard error of 1 548), which led to non-significant differences in soil classes, while the difference between soil classes (C3 and C1) was significant for LAI, PH, TDM, and physiological parameters. Triticale grown in soil class $\mathrm{C} 1$ performed better than in soil class C3, except for C3 soils at US (Fig. 11). The HI, number of grains per ear, and TKW also showed significant differences between elevation and soil classes and confirmed yield results. A significantly positive association was found between grain yield and yield components with AWC in the soil profile. In addition, average SM contents in the top layer (June 10th) had high correlation coefficients with AWC in the soil profile (Fig. 12). The effects of soil properties and elevation on cereal yield (corn, winter wheat and spring barley) have been confirmed in previous studies (Chen et al., 2021; Jiang \& Thelen, 2004; Kumhálová et al., 2011; Timlin et al., 1998), while no specific study has investigated the response of winter triticale yield to elevation and in-field soil heterogeneity, although limited studies have assessed different factors like soil tillage and type, nitrogen, and irrigation under different climatic conditions (temperate-continental to tropical mountain climate) and soil types (Rhodic Hapludox with clay loam texture) (Dumbravă et al., 2016; Estrada-Campuzano et al., 2012; Guedes Filho et al., 2010). Low ear and tiller densities are indicators of drought stress during tillering and stem elongation stages. A greater number of tillers were produced in soil class C3 at DS compared to those of other combinations. However, many green tillers were identified at the time of maturity in triticale in $\mathrm{C} 3$ at DS, where sandy soils are dominant with poor water retention and low AWC (Table 2 and Fig. 4). In 2020, soil water was limited for the plants during April and May (stem elongation, booting and heading stages). Precipitation amounts in April (6 mm) and May (27 mm) were unable to meet the water requirements of the crop (Fig. 2 and Table 5) during the peak vegetative growth period in April and May. However, thereafter at the end of June and in July, rainfall exceeded $60 \mathrm{~mm}$, which promoted the formation of new (green) tillers. The results of the ear and tiller densities with a high share of green tillers confirmed that, although tillers were reduced due to drought stress during early phases as tillers, in later stages, with the increasing availability of water, plants developed new tillers (Bodner et al., 2015). SM measurements were collected on May 7th and June 10th (end of flowering and beginning of grain formation phase) as water stress at these stages leads to the reduction in yield and smaller grain size (Estrada-Campuzano et al., 2012; Rampino et al., 2006). SM results confirmed the differences among soil classes and elevations as top soil moisture $(15 \mathrm{~cm})$, while differences in elevation were also significant for SM measurements at 230 and 264 DAS. As SM data were collected manually, some values were missing at deeper depths due to penetration issues of the auger and SM probe. Non-significant differences may have occurred due to missing values, but topsoil layers in soil class C3 at DS had significantly lower SM values than those in soil class C3 at US. However, the correlation map showed a significant correlation between grain yield and grain attributes with AWC (AWCWL (whole layer)), and average SM in the top soil layers for June 10th measurements. As 
this was at the beginning of grain formation, SM content has a significant effect on yield. Meanwhile, SM recorded at the crop maturity phase had no significant effect on yield as the crop had almost matured (Fig. 10). Winter triticale is sensitive to water stress, particularly at peak biomass and grain formation phases (Daryanto et al., 2017; Estrada-Campuzano et al., 2012). The observation and literature review showed that spatial heterogeneity and variation in soil properties lead to differences in the availability of moisture and nutrients, ultimately affecting the grain yield and yield-contributing parameters (Table 6).

\section{Conclusions}

In the present study, the in-field soil heterogeneity at a farmer's field of a 6.3 hectares was assessed and characterized in a hummocky landscape and the effects of soil heterogeneity and elevation on the growth, physiology, and yield of triticale were quantified. Sandy soil texture was found dominant in the topsoil while variation in soil organic matter and available water capacity in the root zone led to soil heterogeneity (data from 88 soil auguring profiles). The results showed that high spatial in-field heterogeneity and elevation gradients affect triticale growth, yield, and yield attributes. Based on the soil mapping, resulting from a simple soil auger mapping along seven transects, and the digital elevation map, the field was further subdivided into areas with strongly contrasting soil water supply, which was strongly related to triticale growth and yield, except for sandy soils in a slight depression at US. Crops on US had $88 \%$ and $43 \%$ higher grain yield $\left(7414 \mathrm{~kg} \mathrm{ha}^{-1}\right)$ than those on DS and MS, respectively. Observations suggest that this exception was due to lateral water fluxes along the slope. These results will support the need for soil information with high spatial resolution and precision farming technologies to manage crops more efficiently in terms of resource use. It is recommended that the mapping approach combining simple soil augering techniques with a digital elevation model should be used to subdivide cropland fields in hummocky landscapes for determining sub-field input intensities to guide precision farming. In the future, such soil and elevation classes could improve the interpretation of yield maps for targeted application of inputs like water and nutrients for precision management and improved resource use efficiency under temperate climate conditions.

Supplementary Information The online version contains supplementary material available at https://doi. org/10.1007/s11119-021-09868-x.

Acknowledgements The presented study has partially been funded by the German Federal Ministry of Education and Research (BMBF) in the framework of the DAKIS project (Grant Number 031B0729E) and by the Deutsche Forschungsgemeinschaft (DFG, German Research Foundation) under Germany's Excellence Strategy-EXC 2070-390732324 (PhenoRob). APC will be provided through the University of Bonn, Germany.

Author contributions TG and HEA developed the study concept project and obtained funding. MHR, TG, AR and HEA conceptualized the study and established the methods. MHR, AR, HH, TG, and HEA carried out fieldwork. MHR and AR carried out the statistical data analysis. The first manuscript draft was written by MHR while revised and improved by all co-authors. All authors contributed to the intellectual content expressed herein.

Funding Open Access funding enabled and organized by Projekt DEAL.

\section{Declarations}

Conflict of interest The authors declared that there is no conflict of interest. 
Open Access This article is licensed under a Creative Commons Attribution 4.0 International License, which permits use, sharing, adaptation, distribution and reproduction in any medium or format, as long as you give appropriate credit to the original author(s) and the source, provide a link to the Creative Commons licence, and indicate if changes were made. The images or other third party material in this article are included in the article's Creative Commons licence, unless indicated otherwise in a credit line to the material. If material is not included in the article's Creative Commons licence and your intended use is not permitted by statutory regulation or exceeds the permitted use, you will need to obtain permission directly from the copyright holder. To view a copy of this licence, visit http://creativecommons.org/licenses/by/4.0/.

\section{References}

Basso, B., Dumont, B., Cammarano, D., Pezzuolo, A., Marinello, F., \& Sartori, L. (2016). Environmental and economic benefits of variable rate nitrogen fertilization in a nitrate vulnerable zone. Science of the Total Environment. https://doi.org/10.1016/j.scitotenv.2015.12.104

Baxter, S. (2007). Guidelines for soil description. Rome: Food and Agriculture Organization of the United Nations. (2006), pp. 108, US\$40.00. ISBN 92-5-1055-21-1. Experimental Agriculture. https://doi.org/10.1017/s0014479706384906

Beehler, J., Fry, J., Negassa, W., \& Kravchenko, A. (2017). Impact of cover crop on soil carbon accrual in topographically diverse terrain. Journal of Soil and Water Conservation, 72(3), 272-279. https:// doi.org/10.2489/jswc.72.3.272

Beuschel, R., Piepho, H. P., Joergensen, R. G., \& Wachendorf, C. (2019). Similar spatial patterns of soil quality indicators in three poplar-based silvo-arable alley cropping systems in Germany. Biology and Fertility of Soils, 55(1), 1-14. https://doi.org/10.1007/s00374-018-1324-3

Beuschel, R., Piepho, H. P., Joergensen, R. G., \& Wachendorf, C. (2020). Effects of converting a temperate short-rotation coppice to a silvo-arable alley cropping agroforestry system on soil quality indicators. Agroforestry Systems, 94(2), 389-400. https://doi.org/10.1007/s10457-019-00407-2

Bodner, G., Nakhforoosh, A., \& Kaul, H. P. (2015). Management of crop water under drought: A review. Agronomy for Sustainable Development. https://doi.org/10.1007/s13593-015-0283-4

Buttafuoco, G., Castrignanò, A., Cucci, G., Lacolla, G., \& Lucà, F. (2017). Geostatistical modelling of within-field soil and yield variability for management zones delineation: A case study in a durum wheat field. Precision Agriculture, 18(1), 37-58. https://doi.org/10.1007/s11119-016-9462-9

Cardinael, R., Guenet, B., Chevallier, T., Dupraz, C., Cozzi, T., \& Chenu, C. (2018). High organic inputs explain shallow and deep SOC storage in a long-term agroforestry system-Combining experimental and modeling approaches. Biogeosciences, 15(1), 297-317. https://doi.org/10.5194/ bg-15-297-2018

Cardoso, E. J. B. N., Vasconcellos, R. L. F., Bini, D., Miyauchi, M. Y. H., dos Santos, C. A., Alves, P. R. L., et al. (2013). Soil health: Looking for suitable indicators. What should be considered to assess the effects of use and management on soil health? Scientia Agricola, 70(4), 274-289. https://doi.org/10. 1590/S0103-90162013000400009

Castrignanò, A., Buttafuoco, G., Quarto, R., Parisi, D., Viscarra Rossel, R. A., Terribile, F., et al. (2018). A geostatistical sensor data fusion approach for delineating homogeneous management zones in Precision Agriculture. CATENA. https://doi.org/10.1016/j.catena.2018.05.011

Chen, S., Du, T., Wang, S., Parsons, D., Wu, D., Guo, X., \& Li, D. (2020). Evaluation and simulation of spatial variability of soil property effects on deep percolation and nitrate leaching within a large-scale field in arid Northwest China. Science of the Total Environment. https://doi.org/10.1016/j.scitotenv. 2020.139324

Chen, S., Du, T., Wang, S., Parsons, D., Wu, D., Guo, X., \& Li, D. (2021). Quantifying the effects of spatial-temporal variability of soil properties on crop growth in management zones within an irrigated maize field in Northwest China. Agricultural Water Management. https://doi.org/10.1016/j.agwat. 2020.106535

Daryanto, S., Wang, L., \& Jacinthe, P. A. (2017). Global synthesis of drought effects on cereal, legume, tuber and root crops production: A review. Agricultural Water Management. https://doi.org/10.1016/j. agwat.2016.04.022

Dercon, G., Deckers, J., Poesen, J., Govers, G., Sánchez, H., Ramírez, M., et al. (2006). Spatial variability in crop response under contour hedgerow systems in the Andes region of Ecuador. Soil and Tillage Research, 86(1), 15-26. https://doi.org/10.1016/j.still.2005.01.017 
Dumbravă, M., Ion, V., Epure, L. I., Băşa, A. G., Ion, N., \& Duşa, E. M. (2016). Grain yield and yield components at triticale under different technological conditions. Agriculture and Agricultural Science Procedia, 10, 94-103. https://doi.org/10.1016/j.aaspro.2016.09.023

Erekul, O., \& Köhn, W. (2006). Effect of weather and soil conditions on yield components and bread-making quality of winter wheat (Triticum aestivum L.) and winter triticale (Triticosecale Wittm) varieties in north-east Germany. Journal of Agronomy and Crop Science, 192(6), 452-464. https://doi.org/10. 1111/j.1439-037X.2006.00234.X

Estrada-Campuzano, G., Slafer, G. A., \& Miralles, D. J. (2012). Differences in yield, biomass and their components between triticale and wheat grown under contrasting water and nitrogen environments. Field Crops Research, 128, 167-179. https://doi.org/10.1016/j.fcr.2012.01.003

Ferrara, R. M., Trevisiol, P., Acutis, M., Rana, G., Richter, G. M., \& Baggaley, N. (2010). Topographic impacts on wheat yields under climate change: Two contrasted case studies in Europe. Theoretical and Applied Climatology, 99(1-2), 53-65. https://doi.org/10.1007/s00704-009-0126-9

Guedes Filho, O., Vieira, S. R., Chiba, M. K., Nagumo, C. H., \& Dechen, S. C. F. (2010). Spatial and temporal variability of crop yield and some rhodic hapludox properties under no-tillage. Revista Brasileira De Ciencia Do Solo, 34(1), 1-14. https://doi.org/10.1590/s0100-06832010000100001

Gutzler, C., Helming, K., Balla, D., Dannowski, R., Deumlich, D., Glemnitz, M., et al. (2015). Agricultural land use changes - A scenario-based sustainability impact assessment for Brandenburg, Germany. Ecological Indicators, 48, 505-517. https://doi.org/10.1016/j.ecolind.2014.09.004

Hao, X., Thelen, K., \& Gao, J. (2010). Effects of soil and topographic properties on spatial variability of corn grain ethanol yield. Agronomy Journal. https://doi.org/10.2134/agronj2009.0481

Hatfield, J. L., \& Prueger, J. H. (2015). Temperature extremes: Effect on plant growth and development. Weather and Climate Extremes, 10, 4-10. https://doi.org/10.1016/j.wace.2015.08.001

Heller, C., \& Zeitz, J. (2012). Stability of soil organic matter in two northeastern German fen soils: The influence of site and soil development. Journal of Soils and Sediments, 12(8), 1231-1240. https://doi. org/10.1007/s11368-012-0500-6

Huang, X., Wang, L., Yang, L., \& Kravchenko, A. N. (2008). Management effects on relationships of crop yields with topography represented by wetness index and precipitation. Agronomy Journal, 100(5), 1463-1471. https://doi.org/10.2134/agronj2007.0325

Jiang, P., \& Thelen, K. D. (2004). Effect of soil and topographic properties on crop yield in a north-central corn-soybean cropping system. Agronomy Journal. https://doi.org/10.2134/agronj2004.0252

Kravchenko, A. N., \& Bullock, D. G. (2000). Correlation of corn and soybean grain yield with topography and soil properties. Agronomy Journal. https://doi.org/10.2134/agronj2000.92175x

Kravchenko, A. N., Thelen, K. D., Bullock, D. G., \& Miller, N. R. (2003). Relationship among crop grain yield, topography, and soil electrical conductivity studied with cross-correlograms. Agronomy Journal, 95(5), 1132-1139. https://doi.org/10.2134/agronj2003.1132

Kumhálová, J., Kumhála, F., Kroulík, M., \& Matějková, Š. (2011). The impact of topography on soil properties and yield and the effects of weather conditions. Precision Agriculture, 12(6), 813-830. https://doi. org/10.1007/s11119-011-9221-X

Ladoni, M., Basir, A., Robertson, P. G., \& Kravchenko, A. N. (2016). Scaling-up: Cover crops differentially influence soil carbon in agricultural fields with diverse topography. Agriculture, Ecosystems and Environment. https://doi.org/10.1016/j.agee.2016.03.021

Lange, F.-M., Mohr, H., Lehmann, A., Haaff, J., \& Stahr, K. (2017). Bodenmanagement in der Praxis. Bodenmanagement in Der Praxis. https://doi.org/10.1007/978-3-658-10059-9

Libohova, Z., Seybold, C., Wysocki, D., Wills, S., Schoeneberger, P., Williams, C., et al. (2018). Reevaluating the effects of soil organic matter and other properties on available water-holding capacity using the National Cooperative Soil Survey Characterization Database. Journal of Soil and Water Conservation, 73(4), 411-421. https://doi.org/10.2489/jswc.73.4.411

Lipsius, K. (2002). Estimating Available Water Capacity from basic Soil physical Properties -A comparison of common Pedotransfer Functions.

Marchant, B., Rudolph, S., Roques, S., Kindred, D., Gillingham, V., Welham, S., et al. (2019). Establishing the precision and robustness of farmers' crop experiments. Field Crops Research, 230, 31-45. https:// doi.org/10.1016/j.fcr.2018.10.006

Meier, U. (2001). Growth stages of mono- and dicotyledonous plants. BBCH Monograph.

Metwally, M. S., Shaddad, S. M., Liu, M., Yao, R. J., Abdo, A. I., Li, P., et al. (2019). Soil properties spatial variability and delineation of site-specific management zones based on soil fertility using fuzzy clustering in a hilly field in Jianyang, Sichuan, China. Sustainability (Switzerland). https://doi.org/10.3390/ su1 1247084

Munsell, color. (1994). Munsell Soil Color Charts. Munsell Soil Color Charts. 
Nawar, S., Corstanje, R., Halcro, G., Mulla, D., \& Mouazen, A. M. (2017). Delineation of soil management zones for variable-rate fertilization: A review. Advances in Agronomy. https://doi.org/10.1016/bs. agron.2017.01.003

Palm, C., Blanco-Canqui, H., DeClerck, F., Gatere, L., \& Grace, P. (2014). Conservation agriculture and ecosystem services: An overview. Agriculture, Ecosystems and Environment. https://doi.org/10.1016/j. agee.2013.10.010

Panagos, P., Standardi, G., Borrelli, P., Lugato, E., Montanarella, L., \& Bosello, F. (2018). Cost of agricultural productivity loss due to soil erosion in the European Union: From direct cost evaluation approaches to the use of macroeconomic models. Land Degradation and Development. https://doi.org/ 10.1002/ldr.2879

Patzold, S., Mertens, F. M., Bornemann, L., Koleczek, B., Franke, J., Feilhauer, H., \& Welp, G. (2008). Soil heterogeneity at the field scale: A challenge for precision crop protection. Precision Agriculture, 9(6), 367-390. https://doi.org/10.1007/s11119-008-9077-x

Poffenbarger, H. J., Olk, D. C., Cambardella, C., Kersey, J., Liebman, M., Mallarino, A., et al. (2020). Whole-profile soil organic matter content, composition, and stability under cropping systems that differ in belowground inputs. Agriculture, Ecosystems and Environment, 291, 106810. https://doi. org/10.1016/j.agee.2019.106810

Powlson, D. S., Gregory, P. J., Whalley, W. R., Quinton, J. N., Hopkins, D. W., Whitmore, A. P., et al. (2011). Soil management in relation to sustainable agriculture and ecosystem services. Food Policy. https://doi.org/10.1016/j.foodpol.2010.11.025

Quiroga, A., Funaro, D., Noellemeyer, E., \& Peinemann, N. (2006). Barley yield response to soil organic matter and texture in the Pampas of Argentina. Soil and Tillage Research, 90(1-2), 63-68. https:// doi.org/10.1016/j.still.2005.08.019

Rampino, P., Pataleo, S., Gerardi, C., Mita, G., \& Perrotta, C. (2006). Drought stress response in wheat: Physiological and molecular analysis of resistant and sensitive genotypes. Plant, Cell and Environment. https://doi.org/10.1111/j.1365-3040.2006.01588.x

Russ, A., \& Riek, W. (2011). Pedotransferfunktionen zur ableitung der nutzbaren feldkapazität-validierung für waldböden des nordostdeutschen tieflands. Waldokologie Online, 11, 5-17.

Saito, H., McKenna, S. A., Zimmerman, D. A., \& Coburn, T. C. (2005). Geostatistical interpolation of object counts collected from multiple strip transects: Ordinary kriging versus finite domain kriging. Stochastic Environmental Research and Risk Assessment, 19(1), 71-85. https://doi.org/10.1007/ s00477-004-0207-3

Schweitzer, K., \& Hierath, C. (2010). Use of sandy soils in the context with regional soil diversity and soil productivity. International Conference on Soil Fertility and Soil Productivity. Differences of Efficiency of Soils for Land Uses, Expenditures and Returns, (March), 31.

Sida, T. S., Baudron, F., Kim, H., \& Giller, K. E. (2018). Climate-smart agroforestry: Faidherbia albida trees buffer wheat against climatic extremes in the Central Rift Valley of Ethiopia. Agricultural and Forest Meteorology, 248, 339-347. https://doi.org/10.1016/j.agrformet.2017.10.013

Song, Y., Wang, J., Shang, J., \& Liao, C. (2020). Using UAV-based SOPC derived LAI and SAFY model for biomass and yield estimation of winter wheat. Remote Sensing, 12(15), 1-22. https://doi.org/10. 3390/RS12152378

Svoboda, N., Strer, M., \& Hufnagel, J. (2015). Rainfed winter wheat cultivation in the North German Plain will be water limited under climate change until 2070. Environmental Sciences Europe, 27(1), 1-7. https://doi.org/10.1186/s12302-015-0061-6

Tariq, A., Gunina, A., \& Lamersdorf, N. (2018). Initial changes in soil properties and carbon sequestration potential under monocultures and short-rotation alley coppices with poplar and willow after three years of plantation. Science of the Total Environment, 634, 963-973. https://doi.org/10. 1016/j.scitotenv.2018.03.391

Techen, A. K., Helming, K., Brüggemann, N., Veldkamp, E., Reinhold-Hurek, B., Lorenz, M., et al. (2020). Soil research challenges in response to emerging agricultural soil management practices. Advances in Agronomy. https://doi.org/10.1016/bs.agron.2020.01.002

Timlin, D. J., Pachepsky, Y., Snyder, V. A., \& Bryant, R. B. (1998). Spatial and temporal variability of corn grain yield on a hillslope. Soil Science Society of America Journal. https://doi.org/10.2136/ sssaj1998.03615995006200030032x

Twum, E. K. A., \& Nii-Annang, S. (2015). Impact of soil compaction on bulk density and root biomass of Quercus petraea L. at reclaimed post-lignite mining site in Lusatia Germany. Applied and Environmental Soil Science. https://doi.org/10.1155/2015/504603

Vieira, S. R., \& Gonzalez, A. P. (2003). Analysis of the spatial variability of crop yield and soil properties in small agricultural plots. Bragantia, 62(1), 127-138. https://doi.org/10.1590/S0006-87052 003000100016 
Wallor, E., Kersebaum, K. C., Ventrella, D., Bindi, M., Cammarano, D., Coucheney, E., et al. (2018). The response of process-based agro-ecosystem models to within-field variability in site conditions. Field Crops Research, 228, 1-19. https://doi.org/10.1016/j.fcr.2018.08.021

Wang, X., Zhao, Y., Liu, H., Xiao, W., \& Chen, S. (2020). Evaluating the water holding capacity of multilayer soil profiles using hydrus-1d and multi-criteria decision analysis. Water (Switzerland). https://doi.org/10.3390/w12030773

Whitman, C. E., Hatfield, J. L., \& Reginato, R. J. (1985). Effect of slope position on the microclimate, growth, and yield of barley 1. Agronomy Journal, 77(5), 663-669. https://doi.org/10.2134/agron j1985.00021962007700050002x

Xue, W., Bezemer, T. M., \& Berendse, F. (2019). Soil heterogeneity and plant species diversity in experimental grassland communities: Contrasting effects of soil nutrients and $\mathrm{pH}$ at different spatial scales. Plant and Soil, 442(1-2), 497-509. https://doi.org/10.1007/s11104-019-04208-5

Xue, W., Huang, L., \& Yu, F. H. (2016). Spatial heterogeneity in soil particle size: Does it affect the yield of plant communities with different species richness? Journal of Plant Ecology, 9(5), 608-615. https:// doi.org/10.1093/jpe/rtv082

Yang, C., Su, Z. . An., Fan, J. Rong., Fang, H. Dong., Shi, L. Tao., Zhang, J. Hui., et al. (2020). Simulation of the landform change process on a purple soil slope due to tillage erosion and water erosion using UAV technology. Journal of Mountain Science, 17(6), 1333-1344. https://doi.org/10.1007/ s11629-019-5869-X

Yao, R. J., Yang, J. S., Zhang, T. J., Gao, P., Wang, X. P., Hong, L. Z., \& Wang, M. W. (2014). Determination of site-specific management zones using soil physico-chemical properties and crop yields in coastal reclaimed farmland. Geoderma, 232-234, 381-393. https://doi.org/10.1016/j.geoderma.2014. 06.006

Zhang, S., Zhang, X., Liu, Z., Sun, Y., Liu, W., Dai, L., \& Fu, S. (2014). Spatial heterogeneity of soil organic matter and soil total nitrogen in a Mollisol watershed of Northeast China. Environmental Earth Sciences, 72(1), 275-288. https://doi.org/10.1007/s12665-014-3081-4

Zhou, W., Han, G., Liu, M., Zeng, J., Liang, B., Liu, J., \& Qu, R. (2020). Determining the distribution and interaction of soil organic carbon, nitrogen, $\mathrm{pH}$ and texture in soil profiles: A case study in the Lancangjiang river Basin, Southwest China. Forests. https://doi.org/10.3390/F11050532

Publisher's Note Springer Nature remains neutral with regard to jurisdictional claims in published maps and institutional affiliations. 